Review

\title{
From the Structural and (Dys)function of ATP Synthase to Deficiency in Age-Related Diseases
}

\author{
Caterina Garone ${ }^{1,2,3 *}$, Andrea Pietra ${ }^{1,4}$ and Salvatore Nesci 5,* \\ 1 Department of Medical and Surgical Sciences, Alma Mater Studiorum University of Bologna, via \\ Massarenti, 9 - 40137 Bologna, Italy 1; C.G. caterina.garone@unibo.it; A.P. andrea.pietra@studio.unibo.it \\ 2 Center for Applied Biomedical Research, Alma Mater Studiorum University of Bologna, via Massarenti, 9 - \\ 40137 Bologna, Italy 1; caterina.garone@unibo.it \\ 3 IRCCS Istituto delle Scienze Neurologiche di Bologna, UOC Neuropsichiatria dell'età Pediatrica, Bologna; \\ caterina.garone@unibo.it \\ 4 IRCCS Azienda Ospedaliero-Universitaria di Bologna, UO Genetica Medica; andrea.pietra@studio.unibo.it \\ 5 Department of Veterinary Medical Sciences, Alma Mater Studiorum University of Bologna, via Tolara di \\ Sopra, 50 - 40064 Ozzano Emilia, Italy; salvatore.nesci@unibo.it \\ * Correspondence: caterina.garone@unibo.it; Tel.: +39 0512094763 (C.G.); salvatore.nesci@unibo.it; Tel.: +39 \\ 0512097004 (S.N.)
}

\begin{abstract}
The ATP synthase is a mitochondrial complex embedded in the inner mitochondrial membrane. The enzyme is under the double genetic control of the mitochondrial DNA (mtDNA) and nuclear DNA (nDNA). Fatal human diseases have been associated with defects in ATP synthase (Complex V) activity linked to mtDNA or nDNA pathogenetic variants in genes encoding structural subunits or assembly factors. Mitochondrial post-translational modifications of key amino acids, reduced/increased subunit expression, or protein to protein ATP synthase interaction, are also some of the mechanisms involved in the age-related disease pathway. All the major neurodegenerative diseases: Parkinson's, Alzheimer's and motor neuron diseases such as Amyotrophic Lateral Sclerosis highlight an impaired ATP generation in a mechanism involving the permeability transition pore that triggers a cellular homeostasis failure responsible for different forms of regulated cell death. In this review, we will explore ATP synthase assembly and function in physiological and pathological conditions by referring to the recent cryo-EM studies and by exploring human diseases models.
\end{abstract}

Keywords: mitochondria; ATP synthase; cell death; neurodegenerative diseases

\section{Introduction}

Cell survival relies on energy production in form of ATP (Adenosine Tri-Phosphate) molecules, the universal energy currency for all living organisms. The mitochondria, known as the cellular powerhouse, are the energy-producing organelles of the cell [1]. Unique characteristics are the presence of his own DNA (mtDNA) exclusively inherited from the mother and the dual control of both nuclear (nDNA) and mtDNA responsible for encoding around 1500 proteins playing role in mitochondrial function and maintenance. ATP synthase (EC 3.6.1.34), also known as complex V, is composed of 18 protein subunits, 16 nDNA encoded and $2 \mathrm{mtDNA}$ encoded. The main function is the conversion of ADP into ATP, thanks to the proton gradient generated by complexes I to IV and activating the rotor mechanism. Being essential in aerobic cells, the basic structure and catalytic mechanisms of ATP synthase are highly conserved across the species from bacteria to eukaryotes [2,3]. Moreover, the enzyme is involved in the morphology of mitochondria by contributing to generating the inner membrane cristae, an event that evolves to include membrane "supernumerary" subunits [4]. The ATP synthase is a key participant in the cell bioenergetic machinery [5] by highlighting the prominent feature of the "enzyme of life". Otherwise, the mitochondrial dysfunction may arise from to molecular switch of the ATP synthase function that occurs with the "supernumerary" subunits modification by stimulating different forms of regulated cell death [6]. The physio(patho)logical phenomenon might include the $\mathrm{Ca}^{2+}$-dependent permeability transition of 
the mitochondrial inner membrane to ions and solutes with molecular mass up to about 1.5 KDa [79]. Evidence highlights the role of this fascinating enzyme complex as a key molecular and enzymatic switch between cell life and death and increases its attractiveness as a pharmacological target and drug design [10].

However, mitochondria can take part in both the development and cell death process, which feature are dependent on the phenomenon that forms a high-conductance channel known as mitochondrial permeability transition pore (mPTP) [11].

The increase of the older population in modern society became a problem in terms of socioeconomic burdens due to higher incidences of age-related neurodegenerative diseases. Therefore, the development of new strategies targeting these pathological features is a timely topic. Poor energy homeostasis linked to mitochondrial dysfunction springs from an impaired or defective energy transduction system, which constitutes the main biochemical damage in a variety of genetic and neuropsychiatric diseases [12].

In several neurodegenerative diseases, protein aggregation and mitochondrial dysfunction are two pathogenic processes responsible for the onset of age-related diseases. Indeed, mitochondrial structural and functional defects are attributable to mitochondrial dynamics impairment leading to neurodegeneration and ageing, Alzheimer's disease (AD), Parkinson's disease (PD), amyotrophic lateral sclerosis (ALS), Huntington's disease (HD). The inhibition of excessive fission reduces the cell death pathway triggered by mitochondrial dysfunction [13]. Therefore, the morphology of mitochondria is intimately involved in ageing by revealing profound age-dependent changes in membrane architecture. The ATP synthase is involved in generating mitochondrial cristae morphology [4]. ATP synthase dimers are arranged in long rows on the tip of cristae together with the MICOS (mitochondrial contact site and cristae organizing system) complex at cristae junctions and cooperate by opposing effects on membrane curvature to the cristae morphology [14]. The membrane remodelling triggered by disassembly of the supramolecular organization of ATP synthase resembles the inner-membrane vesiculation of old mitochondria. In all likelihood, the cristae shorten and collapse with the ATP synthase dimers dissociation that reduces the convex membrane curvature in the IMM.

Age-related decline in bioenergetics, redox homeostasis, and mitochondrial calcium capacity contribute to accelerating pathogenesis. Indeed, the failure of the organisational power of energy flow in cells is the basis of the biological complexity of diseases in ageing [15].

\section{The structure and function of the ATP synthase}

The ATP synthase is a ubiquitous oligomeric complex placed in the energy-transducing membranes of mitochondria, chloroplasts, and bacteria [16]. The transmembrane protonmotive force $(\Delta p)$ is employed by ATP synthase as a source of energy to drive a mechanical rotary mechanism by the membrane-embedded portion of the enzyme ( $\mathrm{Fo}$ ) coupled to the chemomechanical synthesis of ATP from ADP and Pi on the hydrophilic Fi portion (Fig. 1). The $\Delta p$ generated by substrate oxidation during the mitochondrial respiration is dissipated by Fo with torque generation of the rotor permiting the cooperative ATP binding change mechanism of catalytic sites during ATP production [17]. Contrary, during the ATP hydrolysis the enzyme works in reverse as an $\mathrm{H}^{+}$pump and re-energises the IMM. This bifunctional energy transmission mechanism of ATP synthase is unique in biological systems [18]. The membrane-bound rotor consists of a $c$-ring of eight identical helical hairpin structures in close contact with the $a$ subunit. The $c$-ring stoichiometry is species-dependent and tightly related to the mitochondrial bioenergetic cost [2,3]. Each $c$ subunit has an $\mathrm{H}^{+}$-binding site defined by a conserved acidic side chain (Glu58 in mammalian) on the C-terminal helix in the middle of IMM that is dicyclohexylcarbodiimide-sensitive and essential in ATP synthesis or hydrolysis. The $\mathrm{H}^{+}$translocation takes place between two aqueous half-channel in $a$ subunit [19], which asymmetric arrangement dictates the two opposite rotation directions in the ATP synthesis and hydrolysis [20]. The rotation of the $c$-ring is transmitted directly to the $\mathrm{F}_{1}$ domain by the asymmetrical central stalk (composed of $\gamma, \delta$, and $\varepsilon$ subunit) attached by the "foot" to the $c$-ring. The $\gamma$ subunit of the central 
stalk penetrates along the central axis of the $\mathrm{F}_{1}$ domain that contains three non-catalytic $\alpha$ - and three catalytic $\beta$-subunits that alternate in a hexameric $(\alpha \beta)_{3}$ structure around the central stalk (Fig. 1).

The catalytic sites are placed on the $\beta$ subunits at the interface with the $\alpha$ subunits. Each $\beta$ subunit catalyzes the reaction of synthesis or hydrolysis driven by protonmotive force or ATP phosphorylation potential, respectively. During the synthesis, the rotation of the rotor view from the matrix side is in anticlockwise mode, conversely, the clockwise rotation of the rotor supports the ATP hydrolysis. Each $\beta$ subunit transforms an ATP molecule in a complete rotation $\left(360^{\circ}\right)$. Therefore, the ATP synthase produces or hydrolyzes three ATP molecules per cycle. This coordinate mechanism is the molecular event of a "Splendid Molecular Machine" supported by a cooperative binding change mechanism of the $(\alpha \beta)_{3}$ structure [21]. Indeed, the catalytic sites can assume three distinct conformations characterized by a different affinity for adenine nucleotide. The $\beta_{T P}, \beta_{D P}$, and $\beta_{E}$ have three nucleotide bound-states: the first has ATP or ATP analogues in the catalytic site, the second has ATP or ADP, and the third has no bound nucleotide. The affinity for adenine nucleotide decreases in the absence of ATP and permits the "closed" conformation with the $\beta_{\mathrm{TP}}, \beta_{\mathrm{DP}}$ states or "open" state with $\beta_{\mathrm{E}}$. The enzyme kinetics of the catalytic sites requires nucleotide coordination with the essential cofactor $\mathrm{Mg}^{2+}$ [22], which contributes to the catalytic site asymmetry producing the different affinities for ATP [23]. On the contrary, all of the $\alpha$ subunits are bound to the ATP molecule coordinate to the $\mathrm{Mg}^{2+}$ cofactor and do not undergo chemical transformation. The MgATP in the non-catalytic sites has an important role in permitting the detachment of ADP from the $\beta$ sites. In particular, the ATP hydrolysis forms an $\beta_{\mathrm{E}}$ state loaded with ADP in a "half-closed" conformation that could inhibit the ATP synthase in the absence of MgATP into the non-catalytic sites [24].

Recently, Pinke et al have revealed a cryo-EM structure of ATP synthase with the natural cofactor $\mathrm{Mg}^{2+}$ substituted in the catalytic sites by the $\mathrm{Ca}^{2+}[25]$. The ATP synthase activated by $\mathrm{Ca}^{2+}$ as a cofactor sustain only the monofunctional activity of ATP hydrolysis, whereas ATP synthesis is not permitted. In inside-out submitochondrial particles the hydrolysis of ATP in presence of $\mathrm{Ca}^{2+}$ determines the acridine fluorescence unquenching [26]. Conversely, the ATPase activity is modulated by the presence of a protonmotive force [27]. For these opposite results, the $\mathrm{Ca}^{2+}$-dependent ATP hydrolysis coupled to $\mathrm{H}^{+}$pumping activity is debated even if the unidirectional rotational catalysis is retained [28]. However, the pathophysiological role of $\mathrm{Ca}^{2+}$-supported ATP hydrolysis should not be investigated in the activity of ATP synthase (un)coupled to $\mathrm{H}^{+}$translocation, but in the induction of conformational changes that lead to the formation of MPTP [29].

Importantly, a static structure peripheral to the central rotor, which spans for the entire ATP synthase length, acts as a stator to prevent the $(\alpha \beta)_{3}$ rotation torque of the central stalk. The peripheral stalk (PS) ensures the energy transduction mechanism of the enzyme with the hydrophilic $F_{1}$ domain enzyme activity coupled to $\mathrm{H}^{+}$translocation in the hydrophobic Fo domain $[22,30]$. The PS is composed of hydrophilic and hydrophobic subunits. The formers are the Oligomycin SensitivityConferring Protein (OSCP), F6, the soluble portion of the $b$, and $d$ subunit bound to $(\alpha \beta)_{3}$ hexameric structure of the $\mathrm{F}_{1}$ domain, whereas the hydrophobic portion of $b$ and A6L subunits form the embedded portion in the IMM of the PS (Fig. 1). However, prevention of idle rotation of globular catalytic structure of $\mathrm{F}_{1}$ domain with the rotor is allowed by exploiting the elastic feature of the PS and the interdomain hinge movement of the OSCP facilitates the flexible coupling of $\mathrm{F}_{1}$ and $\mathrm{Fo}_{0}$ [31]. 


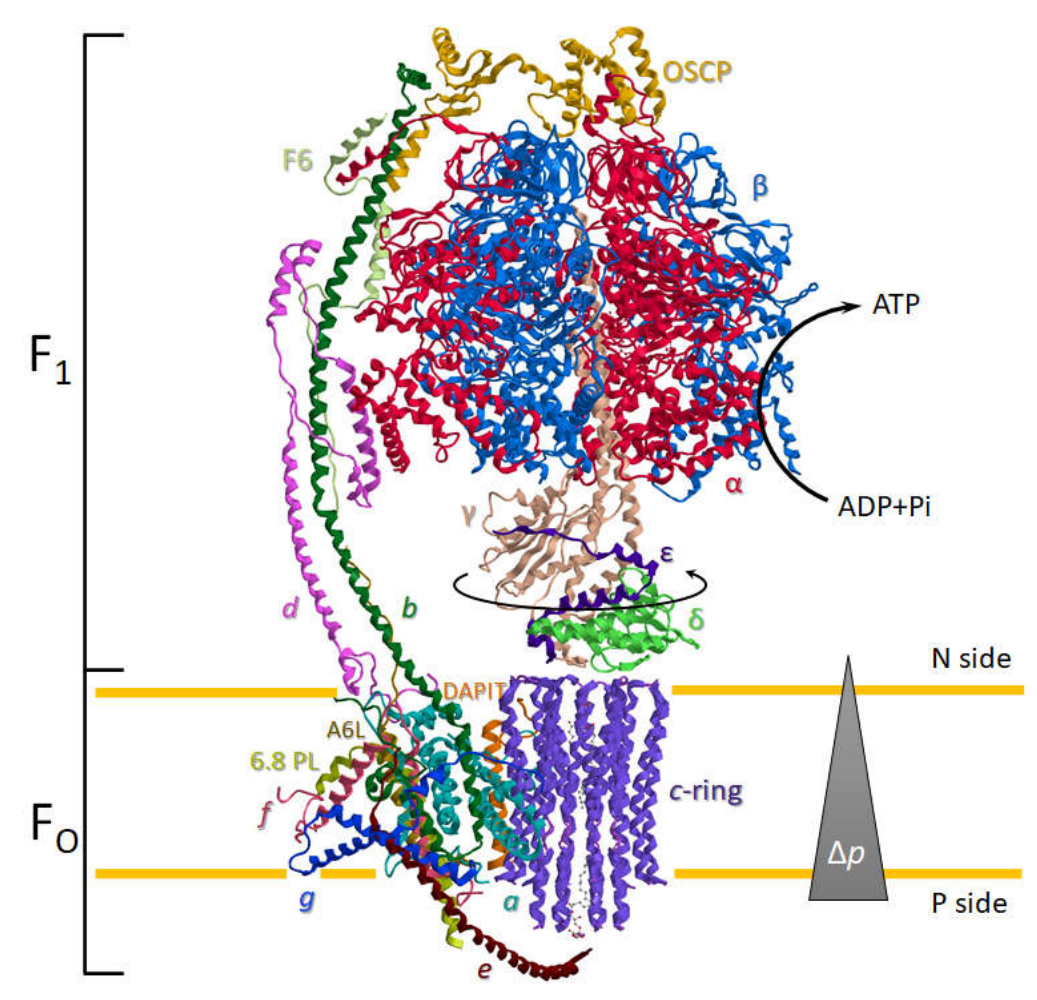

Figure 1. The overall structure of ATP synthase monomers in mammalian mitochondria. Enzyme subunits are drawn as ribbon representations obtained from modified PDB ID codes: 6TT7 [25]. The ATP synthesis is sustained by protonmotive force $(\Delta p)$. The differently coloured letters identify the subunits, drawn in the same colour as the letter. The matrix is the negative side ( $\mathrm{N}$ side), whereas the intracristae space is the positive side ( $\mathrm{P}$ side).

Most of the membrane subunits of the enzyme are encoded by nDNA. Conversely, the membrane subunits identified as $a$, A6L in the mammalian ATP synthase are encoded by the mtDNA. In yeast also the $c$ subunit is encoded by the mtDNA. The latter, express by nDNA in mammals, has three different isoforms. Notably, different supernumerary subunits structurally contribute to the mitochondrial ATP synthase dimerization and IMM curvature (Fig. 2) [32,33]. In the mammalian ATP synthase, these subunits are identified as 6.8-kDa proteolipid (6.8 PL), diabetes-associated protein in insulin-sensitive tissues (DAPIT), A6L, $e, f$, and $g$ and there is one copy of each protein per ATP synthase monomer. The DAPIT, A6L, and $e$ subunit have a single predicted transmembrane $\alpha$-helix, but the latter has a portion of the helix that protrudes into the intracristae space [25]. 
BAR-like domain of monomer'

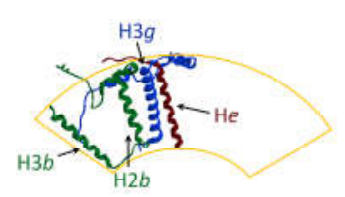

BAR-like domain of monomer"

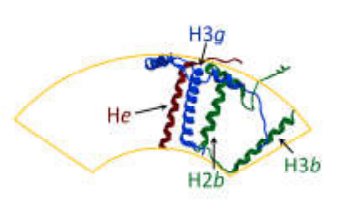

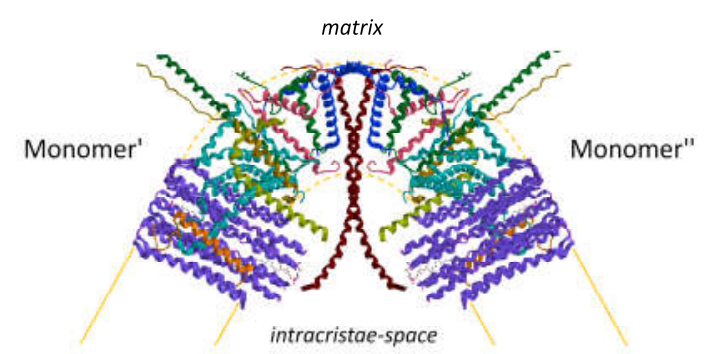
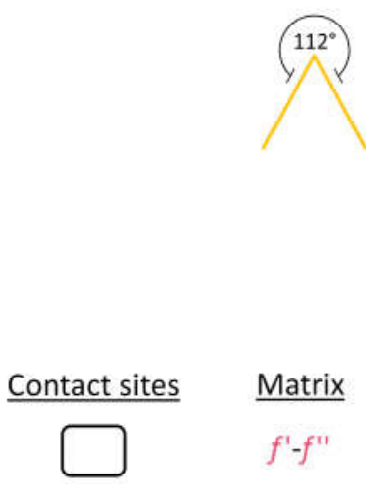

$\frac{\text { Matrix }}{f^{\prime}-f^{\prime \prime}}$
$f^{\prime}-6.8 P L^{\prime \prime}$
$6.8 P L^{\prime}-f^{\prime \prime}$

$\underline{\mathrm{MM}}$

$a^{\prime}-a^{\prime \prime}$

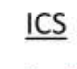

$e^{\prime}-e^{\prime \prime}$

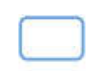

6.8PL'-f'

$e^{\prime}-6.8 P L^{\prime \prime}$ 6.8PL'- $e^{\prime \prime}$
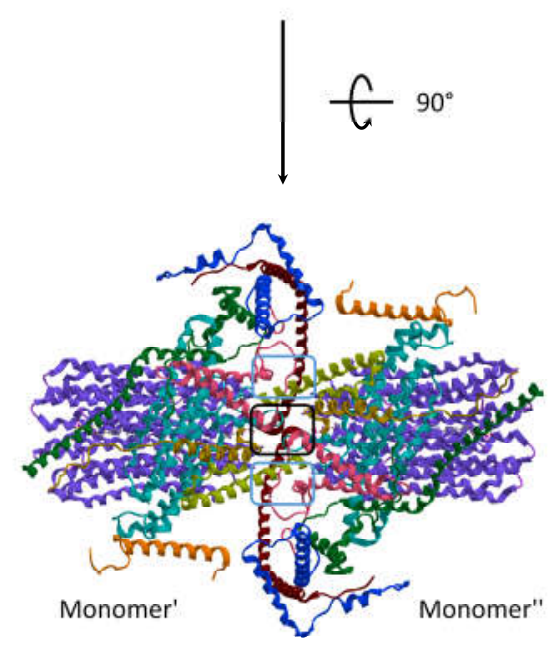

Figure 2. Membrane embedded-domains structure of ATP synthases (obtained from modified PDB ID code: 6TT7). The dimer assembly of monomers in the IMM causes the positive membrane curvature at the cristae tip (upper panel). The transmembrane $\alpha$-helix $(\mathrm{H})$ of subunits that form the BAR-like domain of each monomer are indicated. The angular association of monomers induces the strong curvature of the IMM with indicated angles of $112^{\circ}$. The contacts at the dimer interface are identified inside the boxes (bottom panel). The letter colours are the same as those of the subunits to which the structures belong. MM, middle of the membrane; ICS, intracristae space.

Two monomers of ATP synthase are joined together and some subunit-subunit interactions are involved in IMM bending. The convex angle of $112^{\circ}$ at the tip of the cristae (Fig. 2) arises from a reminiscent BAR-like domain [34] that bends the lipid bilayer to the highly curved apex of the cristae. The structural composition of the subunits includes the single helix $(\mathrm{H})$ of the $e$ subunit with its transmembrane portion, the third $\alpha$-helix of the three $\alpha$-helices of the $g$ subunit $(\mathrm{H} 3 g)$, and the H2 and $\mathrm{H} 3$ of the $b$ subunit. The topology of the Hs distribution in the BAR-like domain is responsible for a $61^{\circ}$ angle of IMM (Fig. 2). Three distinct contact sites take place between two monomers during the ATP synthase dimerization: two of them laterally to the dimer, respectively in the inner layer of the IMM, facing the matrix, and in the outer layer facing the intracristae space whereas a third site is located in the middle of the supramolecular structure. The subunits involved in the interaction are the $f$ and the 6.8 PL subunit of neighbours monomers of the same dimer at the matrix side. The contact site establish between $e$ and the 6.8 PL of adjacent monomers from the dimer are placed at the intracristae space side. The contact sites in the dimeric core of ATP synthases are arranged between opposite subunits of monomers at the matrix side between $f$ subunits within the IMM, in the middle of the membrane between $a$ subunits, and at the intracristae space between $e$ subunits (Fig. 2).

\section{The hidden face of the ATP synthase}

Even if the overall architecture, organization and mechanistic principles of ATP synthase have been well established in the last decade, other roles of ATP synthase in mitochondrial biology are less well understood. Indeed, the ATP synthase function is not only confined to ATP production but also, as recently emerged, when activated by $\mathrm{Ca}^{2+}[27,29,35,36]$, in the formation of the lethal mega-channel 
in the IMM known as the MPTP [37]. The mPTP would coincide with the ATP synthase [25]. When in the catalytic site the natural cofactor $\mathrm{Mg}^{2+}$ is replaced by $\mathrm{Ca}^{2+}$, the enzyme would disassemble forming the MPTP in the Fo domain. Since the $\mathrm{Ca}^{2+}$-activated ATP synthase differently responds to various modulators with respect to the enzyme activated by natural cofactor $\mathrm{Mg}^{2+}$, biochemical strategies targeting the enzyme may potentially rule the $\mathrm{mPTP}$, on one side to prevent its opening and the associated deadly events, and on the other, to trigger its formation to selectively counteract cell proliferation. This arcane phenomenon raised the research interests in mPTP modulators [38-44], which can represent innovative drugs to counteract a variety of mPTP-related human diseases $[10,45]$. Kinetic analyses in vitro on the ATP synthase inhibition mechanisms and the interaction between different inhibitors, under different assay conditions, have been used as a biochemical strategy to identify and evaluate the effect of post-translational modifications of amino acids (e.g. cysteine, tyrosine, histidine, and arginine) on the molecular mechanisms of energy transduction in mitochondria [38,43,46-49].

Different hypotheses have been proposed to explain the role of ATP synthase as a pore-forming component of the MPTP. The opening of a large conductance channel could be triggered by the $c$-ring of ATP synthase [50,51] or it forms in ATP synthase dimers at the interface between monomers $[52,53]$. However, the recent cryo-EM structure of ATP synthase with the $\mathrm{Ca}^{2+}$ bound to catalytic sites of the enzyme [25] supports the "bent-pull" model [36,54]. So, the MPTP opening arises from different conformations of the $\mathrm{Ca}^{2+}$-activated ATP synthase. The $\mathrm{Ca}^{2+}$ has a higher atomic radius than the natural cofactor $\mathrm{Mg}^{2+}$ by inducing an alteration of the $\mathrm{F}_{1}$ domain. The structural modification of the enzyme catalytic sites is transmitted by the PS to the Fo domain. The conformational changes generate a force that pulls the lipid plug out of the $c$-ring. In all likelihood, the lyso-phosphatidylserine on the intracristae space is pushed out of the hole of the $c$-ring by the movement induced by $e$ subunit. Consistently, the water molecules fill the inside of the $c$-ring and destabilise the phosphatidylserine plug on the matrix side. Accordingly, the $\mathrm{F}_{1}$ detaches from the $\mathrm{Fo}_{\mathrm{O}}$ and the pore opens $[25,36]$ (Fig. 3). 


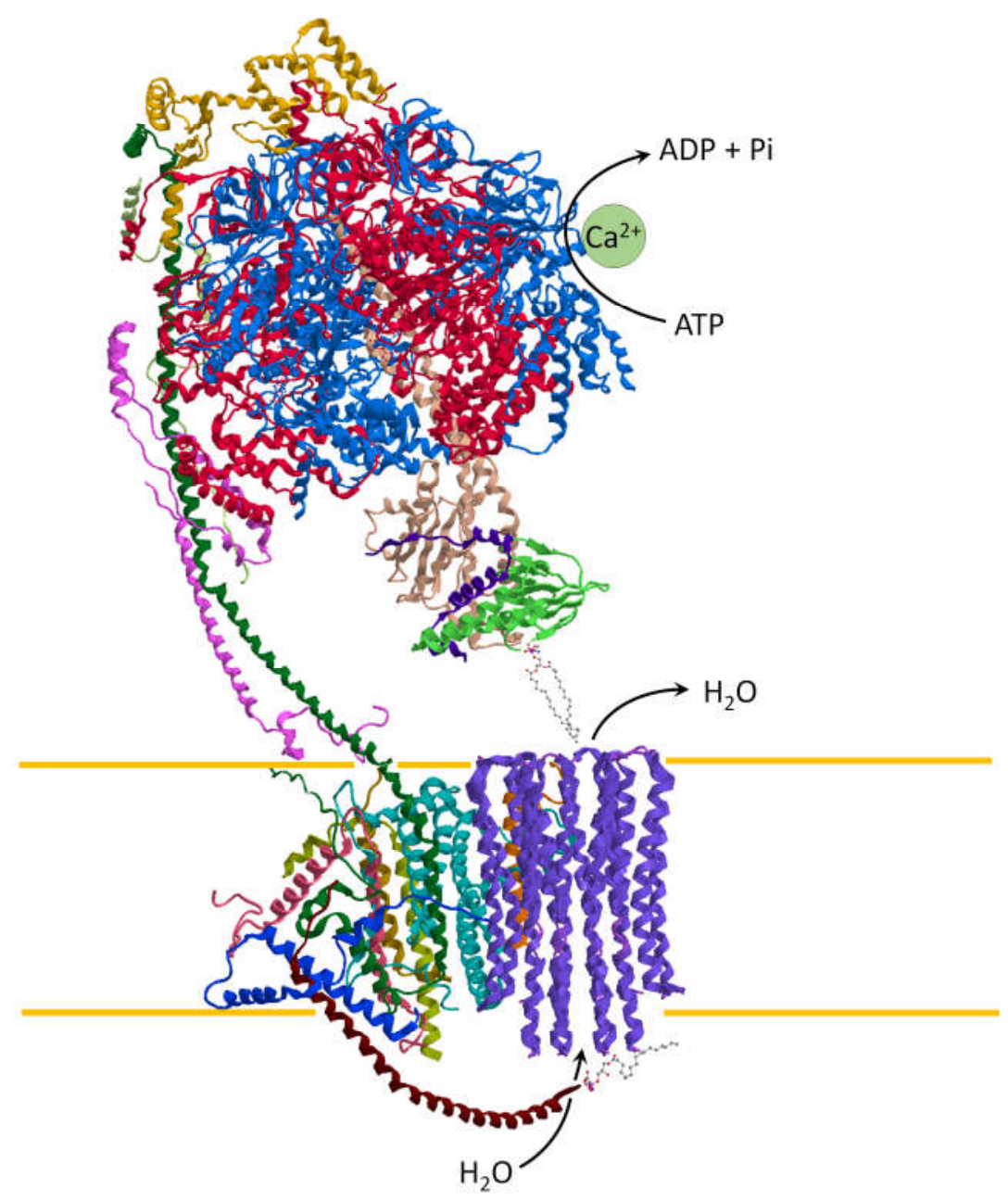

Figure 3. ATP synthase representation, obtained from modified PDB ID code: 6TT7, in the conformation of the MPTP opening. The $\mathrm{Ca}^{2+}$ bound to the catalytic sites drives the ATP hydrolysis by triggering the structural change which forms the MPTP. The pore might open in the core of the $c$ ring when the retracted $e$ subunit pulls the lyso-phosphatidylserine plug out of the $c$-ring at the intracristae space, while stabilized structure of ATP synthase pulls out phosphatidylserine at the matrix side. The mPTP opening dissipates the mitochondrial protonmotive force and water entries in the matrix driven by oncotic pressure.

The $\mathrm{Ca}^{2+}$ signalling propagation pathway of the $\mathrm{Ca}^{2+}$-activated ATP synthase that triggers the mPTP is supported by the unit structure of $b, g$, and $e$ subunit. This structure known as "hook apparatus" performs the mechanism of mPTP formation. Indeed, the conformational changes of ATP hydrolysis supported by $\mathrm{Ca}^{2+}$ as a cofactor in the $\mathrm{F}_{1}$ domain would generate the force transmitted along with the $b$ subunit from the soluble hydrophilic subunits to membrane subunits. In the Fo domain, the $\mathrm{H} 2 b, \mathrm{H} 3 g$, and $\mathrm{He}$ helixes are joined together by salt bridges and assembled in a triple transmembrane helix bundle (TTMHB) (Fig. 4). Moreover, in the TTMHB the $e$ and $g$ subunits are tightly bound by the GxxxG motifs [25]. A lyso-phosphatidylserine (L-PS) is attached to the end of the $\alpha$-helix of $e$ subunit, which fills the hole of the $c$-ring and acts as a lubricating lipid plug allowing rotation of the rotor. The pushing forces on the long helix of the $b$ subunit, which are generated by conformational changes in the $\mathrm{F}_{1}$ domain loaded with $\mathrm{Ca}^{2+}$, pull the L-PS plug out of the $c$-ring by the hook (Fig. 4). Moreover, the modification of the membrane subunits arrangement in the IMM when the MPTP phenomenon is triggered changes the subunit-subunit interaction responsible for dimer formation and membrane curvature at the ridge of the cristae. 

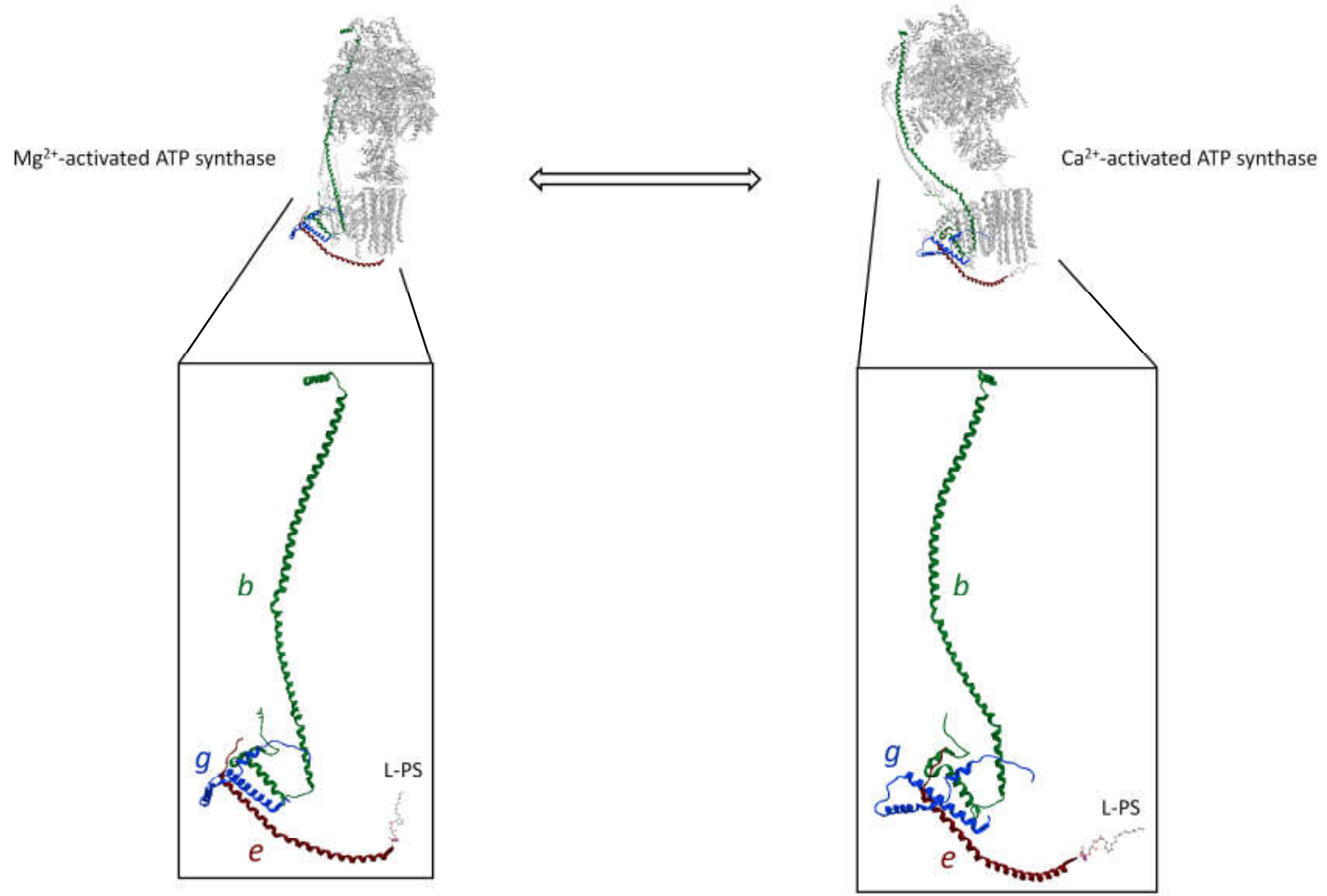

Figure 4. The "hook apparatus" of the ATP synthase (obtained from modified PDB ID code: 6TT7) with a triple transmembrane helix bundle (TTMHB) of $b, g$, and $e$ subunits involved in pulling the lipid when the mPTP opens. The conformations of "hook apparatus" are depicted in the presence of the natural cofactor $\mathrm{Mg}^{2+}$ (on the left) and with $\mathrm{Ca}^{2+}$ (on the right). The differently coloured letters identify the subunits, drawn in the same colour as the letter. All other subunits of ATP synthase are shown in grey. The lyso-phosphatidylserine (L-PS) is illustrated as a ball-and-stick model.

\section{The ATP synthase deficiency}

Mitochondrial integrity and function are crucial for the proliferation, differentiation, and maintenance of neural stem cells (NSCs) in health and disease. During embryonic and adult neurogenesis, NSCs undergo a metabolic switch from glycolytic to oxidative phosphorylation with a rise in mitochondrial DNA (mtDNA) content, changes in mitochondria shape and size, and a physiological augmentation of mitochondrial reactive oxygen species which together drive NSCs to proliferate and differentiate. Defect in nuclear or mtDNA OXPHOS subunits can affect the mechanism responsible for controlling NCS fate, and cause neurodevelopmental disorders, brain malformation, and impaired regenerative capacity in adult stem cells. Moreover, whenever a metabolic requirement goes beyond a sustainable level of metabolic flexibility, mitochondrial dysfunction challenges cellular resilience and brain function and contribute to neurodegeneration [55].

ATP synthase plays a central role in maintaining an adequate bioenergetic metabolism of neural cells other than controlling the mitochondrial dynamic and oxidative ROS production. Therefore, ATP synthase deficiency can be responsible for inherited mitochondrial encephalopathy and contributes to neurodevelopmental and neurodegenerative disorders. Dysfunction may result from structural or enzymatic defects due to aberrant mechanisms of synthesis, assembly, biogenesis and regulation of the ATP synthase complexes [56]. Direct "hits" are genetic variants in nuclear or mitochondrial DNA encoded subunits causing maternal or mendelian inherited mitochondrial disorders while indirect hits are defects in nDNA encoded assembly factors or regulatory and interacting proteins. Although the underlying disease mechanism is different, they all culminate with reduced catalytic activity and profound alteration of mitochondrial morphology with onion-like remodeling of cristae shape. 
MT-ATP6 defect is the most common cause of ATP synthase deficiency associated with maternally inherited mitochondrial encephalopathy with a predominant tissue-specificity for the cerebellum and basal ganglia and frequent multisystemic involvement of muscle, heart, peripheral nervous system, hearing and eye. Clinical features include ataxia, motor and language developmental delay, deafness, retinitis pigmentosa, hypertrophic cardiomyopathy. The first and most common pathogenetic variants, m.8993T >G (p.Leu156Arg) and m.8993T >C (p.Leu156Pro) were described in families presenting the spectrum of Maternal Inherited Leigh syndrome (MILS) and Neurogenic muscle weakness, Ataxia, Retinitis Pigmentosa (NARP) [57,58]. The biochemical defect is more pronounced in the $\mathrm{m} .8993 \mathrm{~T}>\mathrm{G}$ introducing a positively charged amino acid (arginine) in a very highly conserved position (Leu156), consequently affecting the $c$-ring rotation and reducing the proton flux through Fo [59]. More than 70 variants have been described in the literature, 10 of them with confirmed pathogenicity in several independent research studies (www.mitomap.org) [60]. Clinical, neurophysiological and neuroimaging features depict additional three major syndromes: Familiar bilateral striatal necrosis characterized by bilateral symmetrical degeneration of the basal ganglia, predominantly of the caudate and putamen nucleus; [61,62]; Leber Hereditary Optic Neuropathy (LHON) characterized by acute or subacute central vision loss leading to central scotoma and blindness [63]; Charcot-Marie-tooth Neuropathy described in patients with pes cavus, subtle gait unsteadiness, weakness, atrophy and paraesthesia and sensory axial neuropathy [64-66].

Pathogenetic variants of MT-ATP8 are rarer causes of ATP synthase deficiency. Only eight patients have been described presenting with hypertrophic cardiomyopathies, cerebellar ataxia and psychomotor delay the majority of them [65,67]. Additional signs and symptoms were deafness, seizures, spastic paraplegia, neuropathy. Interestingly, Fehli et al. reported a patient with psychomotor delay, global and axial hypotony and seizures and bilateral abnormalities of signal intensity in the bilateral lenticular nucleus, dentate nucleus and periventricular, carrying two homoplasmic variants: m.8392C > T (Pro136Ser) in MT-ATP6 gene and m.8527A $>$ G at the junction MTATP6/MT-ATP8 [68].

Autosomal recessive ATP synthase deficiency has been associated with "direct hits" due to pathogenetic variants in five nuclear-encoded subunits: ATP5A1 encoding for the $\alpha$-subunit in $\mathrm{F}_{1}$ subcomplex, ATP5D and ATP5E respectively encoding for $\delta$ and $\varepsilon$ subunit and forming the central stalk with $\gamma$ subunit, and USMG5, encoding for a protein involved in the dimerization of ATP synthase.

Although they all present with encephalopathy [69-74], a very early onset (birth-day 1 of life) with rapid progression to fatal exitus characterized ATP5A1 defect $[69,70]$ while episodes of metabolic decompensation, consciousness deterioration and psychomotor regression with partial resolution of clinical and neuroimaging features were the striking characteristics of the encephalopathy presented by patients carrying pathogenetic variants in ATP5D [71] and USMG5 [74].

Only two "indirect hits" due to defects in assembly factor (TMEM70, ATPAF2) cause ATP synthase deficiency. ATPAF2 is a nuclear gene encoding a protein that binds single $\alpha$ subunits and allows their bond with $\beta$ subunits avoiding their aggregation in the matrix. A homozygous mutation c.280T $>$ A (p.Trp94Arg) was found in a girl with dysmorphological features (wide mouth, prominent nasal bridge, micrognathia, rocker bottom feet and flexion contractures associated with camptodactyly), hepatomegaly, renal hypoplasia, abnormal urinary excretion of lactate, fumarate, methylglutamic acid and amino acids, rapidly progressing cortico-subcortical and basal ganglia atrophy with dysgenesis of corpus callosum and hypomyelination. The girl died at 14 months of age for recurrent infections [75].

Homozygous variants in TMEM70 gene typically cause hypertrophic cardiomyopathy, arrhythmia, encephalopathy, dysmorphological features, hypotonia, ataxia, difficulty to thrive, psychomotor delay, severe lactic acidosis and 3-MGA [76]. Additional signs and symptoms are microcephaly [77], cataract [78], ptosis [79], myoclonic episodes and an increase of alanine, glutamine/glutamate and ammonium in blood [80] MRI brain showed mild cortical atrophy in some patients [78]. A metabolic crisis may occur at any disease stage and can lead to a fatal outcome [81].

Clinical sign and symptoms of ATP synthase deficiency are summarized in Table 1. 
Table 1 - Clinical signs and symptoms of inherited ATP-synthase deficiency reported in single case report or patients' cohort studies.

\begin{tabular}{|c|c|c|c|c|c|c|c|c|c|c|}
\hline $\begin{array}{l}\text { Gen } \\
\text { e }\end{array}$ & Variants & CNS & PNS & $\begin{array}{l}\text { Mus } \\
\text { cle }\end{array}$ & Heart & EYE & $\begin{array}{l}\text { Brain } \\
\text { MRI }\end{array}$ & $\begin{array}{l}\text { Metaboli } \\
\mathrm{c} \\
\text { alteration } \\
\mathrm{s}\end{array}$ & Other & $\begin{array}{l}\text { Refe } \\
\text { renc } \\
\text { es }\end{array}$ \\
\hline $\begin{array}{l}\text { ATP } \\
5 \mathrm{~A} 1\end{array}$ & $\begin{array}{l}\text { c. } 985 \mathrm{C}>\mathrm{T} \\
\text { (p.Arg329Cys) } \\
\text { c.962A>G } \\
\text { (p.Tyr321Cys) }\end{array}$ & $\begin{array}{l}\text { Enceph } \\
\text { alopath } \\
\text { y } \\
\text { Seizures } \\
\text { Hypoto } \\
\text { nia }\end{array}$ & - & - & $\begin{array}{l}\text { Pulmon } \\
\text { ary } \\
\text { hyperte } \\
\text { nsion } \\
\text { heart } \\
\text { failure }\end{array}$ & - & $\begin{array}{l}\text { Hyperin } \\
\text { tensity } \\
\text { of } \\
\text { thalamu } \\
\text { s and } \\
\text { subcorti } \\
\text { cal } \\
\text { density } \\
\text { Progres } \\
\text { sive } \\
\text { cortical, } \\
\text { subcorti } \\
\text { cal, } \\
\text { cerebell } \\
\text { um and } \\
\text { pons } \\
\text { damage }\end{array}$ & $\begin{array}{l}\text { Hyperala } \\
\text { ninemia }\end{array}$ & $\begin{array}{l}\text { Hypoplastic } \\
\text { lungs } \\
\text { renal cysts } \\
\text { Microcephal } \\
\text { y }\end{array}$ & $\begin{array}{l}{[69]} \\
{[70]}\end{array}$ \\
\hline $\begin{array}{l}\text { ATP } \\
5 \mathrm{D}\end{array}$ & $\begin{array}{l}\text { c.245C>T } \\
\text { (p.Pro82Leu) } \\
\text { c.317T>G } \\
\text { (p.Val106Gly) }\end{array}$ & $\begin{array}{l}\text { Enceph } \\
\text { alopath } \\
\text { y } \\
\text { Letharg } \\
\text { y } \\
\text { Motor } \\
\text { delay } \\
\text { Ataxia } \\
\text { Speech } \\
\text { delay } \\
\text { Myoclo } \\
\text { nic } \\
\text { seizure } \\
\text { Hypoto } \\
\text { nia }\end{array}$ & - & $\begin{array}{l}\text { Proxi } \\
\text { mal } \\
\text { musc } \\
\text { le } \\
\text { weak } \\
\text { ness } \\
\text { exerc } \\
\text { ise } \\
\text { intol } \\
\text { eran } \\
\text { ce }\end{array}$ & $\begin{array}{l}\text { Dilatati } \\
\text { ve } \\
\text { cardio } \\
\text { myopat } \\
\text { hy }\end{array}$ & - & $\begin{array}{l}\text { Transito } \\
\text { ry } \\
\text { widespr } \\
\text { ead } \\
\text { cortical } \\
\text { and } \\
\text { subcorti } \\
\text { cal } \\
\text { oedema }\end{array}$ & $\begin{array}{l}\text { Severe } \\
\text { acidosis, } \\
\text { Hypoglic } \\
\text { aemia, } \\
\text { Hyperam } \\
\text { monaemi } \\
\text { a, } \\
\text { 3-MGA }{ }^{1} \\
\text { Ketoacid } \\
\text { osis }\end{array}$ & Short stature & [71] \\
\hline $\begin{array}{l}\text { ATP } \\
5 \mathrm{E}\end{array}$ & $\begin{array}{l}\text { c.35A>G } \\
\text { (p.Tyr12Cys) }\end{array}$ & Ataxia & $\begin{array}{l}\text { Periphe } \\
\text { ral } \\
\text { neurop } \\
\text { athy }\end{array}$ & $\begin{array}{l}\text { Wea } \\
\text { knes } \\
\text { s }\end{array}$ & $\begin{array}{l}\text { Mild } \\
\text { hypertr } \\
\text { ophy of } \\
\text { left }\end{array}$ & - & - & $\begin{array}{l}\text { Hyperlact } \\
\text { icaemia, } \\
\text { 3MGA'1, } \\
\text { hyperam }\end{array}$ & $\begin{array}{l}\text { Respiratory } \\
\text { distress }\end{array}$ & [73] \\
\hline
\end{tabular}




\begin{tabular}{|c|c|c|c|c|c|c|c|c|c|c|}
\hline & & & & $\begin{array}{l}\text { exerc } \\
\text { ise } \\
\text { intol } \\
\text { eran } \\
\text { ce }\end{array}$ & $\begin{array}{l}\text { ventricl } \\
\mathrm{e}\end{array}$ & & & $\begin{array}{l}\text { monaemi } \\
\text { a }\end{array}$ & & \\
\hline $\begin{array}{l}\text { DA } \\
\text { PIT- } \\
\text { UM } \\
\text { SG5 }\end{array}$ & c. $87+1 G>C($ p.?) & $\begin{array}{l}\text { Motor } \\
\text { delay } \\
\text { Ataxia, } \\
\text { Ophthal } \\
\text { moplegi } \\
\text { a }\end{array}$ & - & - & NA & - & $\begin{array}{l}\text { Brainste } \\
\mathrm{m} \text { and } \\
\text { basal } \\
\text { ganglia } \\
\text { lesions }\end{array}$ & - & NA & [74] \\
\hline $\begin{array}{l}\text { MT- } \\
\text { ATP } \\
6\end{array}$ & $\begin{array}{l}\text { m.9176T>C } \\
\text { (p.Leu217Pro) } \\
\text { m.9185T>C } \\
\text { (p.Leu220Pro) } \\
\text { m.9127_9128del } \\
\text { AT } \\
\text { (p.Ile201ProfsX2) } \\
\text { m.8993T>C } \\
\text { (p.Leu156Pro) } \\
\text { m.9185T>C } \\
\text { (p.Leu220Pro) } \\
\text { m.8993T>G } \\
\text { (p.Leu156Arg) } \\
\text { m.8993T>C } \\
\text { (p.Leu156Pro) } \\
\text { m.9017T>C } \\
\text { (p.Ile164Thr) } \\
\text { and m.9010G>A } \\
\text { (p.Ala162Thr) } \\
\text { m.9025G>A } \\
\text { (p.Gly167Ser) } \\
\text { m.9020A>G } \\
\text { (p.His168Arg) } \\
\text { m.9032T>C } \\
\text { (p.Leu169Pro) } \\
\text { m.9157G>A } \\
\text { (p.Ala211Thr) } \\
\text { m.8618insT } \\
\text { (p.Ile31IlefsX64) } \\
\text { (p.Leu156Arg) }\end{array}$ & $\begin{array}{l}\text { Cerebell } \\
\text { ar ataxia } \\
\text { Myoclo } \\
\text { nic } \\
\text { seizure } \\
\text { Develop } \\
\text { mental } \\
\text { delay } \\
\text { Cogniti } \\
\text { ve } \\
\text { deficit } \\
\text { Motor } \\
\text { delay } \\
\text { Seizures } \\
\text { Hypoto } \\
\text { nia } \\
\text { Spastic } \\
\text { paraple } \\
\text { gy } \\
\text { Dystoni } \\
\text { a Dysarth } \\
\text { ria }\end{array}$ & $\begin{array}{l}\text { Paraest } \\
\text { hesia } \\
\text { Motor } \\
\text { and } \\
\text { sensori } \\
\text { neural } \\
\text { neurop } \\
\text { athy } \\
\text { Peryph } \\
\text { eral } \\
\text { polyne } \\
\text { uropat } \\
\text { hy }\end{array}$ & $\begin{array}{l}\text { Mus } \\
\text { cle } \\
\text { weak } \\
\text { ness } \\
\text { Mus } \\
\text { cle } \\
\text { atrop } \\
\text { hy }\end{array}$ & $\begin{array}{l}\text { Hypertr } \\
\text { ophic } \\
\text { cardio } \\
\text { myopat } \\
\text { hy } \\
\text { Suprav } \\
\text { entricul } \\
\text { ar } \\
\text { arrhyth } \\
\text { mia } \\
\text { Atriove } \\
\text { ntricula } \\
\text { r block } \\
\text { Bradyca } \\
\text { rdia }\end{array}$ & $\begin{array}{l}\text { Optic } \\
\text { atrop } \\
\text { hy } \\
\text { Retin } \\
\text { al } \\
\text { degen } \\
\text { eratio } \\
\text { n } \\
\text { Retini } \\
\text { tis } \\
\text { pigme } \\
\text { ntosa } \\
\text { Nysta } \\
\text { gmus, } \\
\text { Strabi } \\
\text { smus, } \\
\text { Ptosis } \\
\text { Catar } \\
\text { act } \\
\text { Atypi } \\
\text { cal } \\
\text { LHO } \\
\text { N } \\
\text { Blind } \\
\text { ness }\end{array}$ & $\begin{array}{l}\text { Basal } \\
\text { ganglia } \\
\text { lesions } \\
\text { Pituitar } \\
\text { y } \\
\text { atrophy } \\
\text { Medulla } \\
\text {, pons } \\
\text { and } \\
\text { brain } \\
\text { stem } \\
\text { lesions } \\
\text { White } \\
\text { matter } \\
\text { abnorm } \\
\text { alities } \\
\text { Cerebell } \\
\text { ar } \\
\text { vermis } \\
\text { atrophy } \\
\text { Cortical } \\
\text { atrophy } \\
\text { Cerebell } \\
\text { ar } \\
\text { atrophy }\end{array}$ & $\begin{array}{l}\text { Increase } \\
\text { CSF lactic } \\
\text { acid } \\
\text { Lactic } \\
\text { acidosis } \\
\text { Increase } \\
\text { of plasma } \\
\text { pyruvate } \\
\text { and } \\
\text { alanine } \\
\text { Metabolic } \\
\text { acidosis } \\
\text { Hyperam } \\
\text { monaemi } \\
\text { a } \\
\text { Increase } \\
\text { of } \\
\text { creatinine } \\
\text { kinase }\end{array}$ & $\begin{array}{l}\text { Sensorineur } \\
\text { al hearing } \\
\text { loss } \\
\text { Diabetes } \\
\text { mellitus } \\
\text { Hypogonadi } \\
\text { sm } \\
\text { Hypothyroi } \\
\text { dismSurrena } \\
\text { lic failure } \\
\text { Short stature } \\
\text { Respiratory } \\
\text { distress } \\
\text { Dysmorphis } \\
\text { ms } \\
\text { Cafè-au-lait } \\
\text { spot } \\
\text { Deafness } \\
\text { Headache } \\
\text { Renal failure }\end{array}$ & $\begin{array}{l}{[82]} \\
{[83]} \\
{[64]} \\
{[84]} \\
{[66]} \\
{[85]} \\
{[86]} \\
{[87]} \\
{[88]} \\
{[89]} \\
{[90]} \\
{[91]}\end{array}$ \\
\hline
\end{tabular}




\begin{tabular}{|c|c|c|c|c|c|c|c|c|c|c|}
\hline & $\begin{array}{l}\text { m.8993T>G } \\
\text { (p.Leu156Arg) }\end{array}$ & & & & & & & & & \\
\hline $\begin{array}{l}\text { MT- } \\
\text { ATP } \\
8\end{array}$ & $\begin{array}{l}\text { m.8411A>G } \\
\text { (p.Met16Val) } \\
\text { m.8393C }>\text { T } \\
\text { (Pro136Ser) }\end{array}$ & $\begin{array}{l}\text { Develop } \\
\text { mental } \\
\text { delay } \\
\text { Ataxia } \\
\text { Seizure } \\
\text { Letharg } \\
\text { y } \\
\text { Enceph } \\
\text { alopath } \\
\text { y } \\
\text { Tetraple } \\
\text { gia }\end{array}$ & $\begin{array}{l}\text { Neurop } \\
\text { athy }\end{array}$ & $\begin{array}{l}\text { Wea } \\
\text { knes } \\
\text { s }\end{array}$ & $\begin{array}{l}\text { Hypertr } \\
\text { ophic } \\
\text { cardio } \\
\text { myopat } \\
\text { hy } \\
\text { arrhyth } \\
\text { mia }\end{array}$ & $\begin{array}{l}\text { Blind } \\
\text { ness }\end{array}$ & $\begin{array}{l}\text { Cerebell } \\
\text { ar } \\
\text { atrophy, } \\
\text { White } \\
\text { matter } \\
\text { alteratio } \\
\text { ns }\end{array}$ & $\begin{array}{l}\text { Lactic } \\
\text { acidosis } \\
\text { Hyperam } \\
\text { monaemi } \\
\text { a } \\
\text { Hyperala } \\
\text { ninemia } \\
\text { Hypoglic } \\
\text { aemia }\end{array}$ & $\begin{array}{l}\text { Deafness } \\
\text { Anorexia } \\
\text { Respiratory } \\
\text { distress }\end{array}$ & $\begin{array}{l}{[65]} \\
{[67]}\end{array}$ \\
\hline $\begin{array}{l}\text { MT- } \\
\text { ATP } \\
6 \\
/ \text { MT } \\
- \\
\text { ATP } \\
8\end{array}$ & $\begin{array}{l}\mathrm{m} \cdot 8528 \mathrm{~T}>\mathrm{C} \\
\mathrm{m} \cdot 8529 \mathrm{G}>\mathrm{A} \\
\mathrm{m} \cdot 8527 \mathrm{~A}>\mathrm{G}\end{array}$ & $\begin{array}{l}\text { Develop } \\
\text { mental } \\
\text { delay } \\
\text { Seizures }\end{array}$ & $\begin{array}{l}\text { Global } \\
\text { and } \\
\text { axial } \\
\text { hypoto } \\
\text { ny }\end{array}$ & - & - & - & $\begin{array}{l}\text { Lenticul } \\
\text { ar } \\
\text { nucleus } \\
\text { and } \\
\text { white } \\
\text { matter } \\
\text { anomali } \\
\text { es }\end{array}$ & - & - & [68] \\
\hline $\begin{array}{l}\text { ATP } \\
\text { AF2 }\end{array}$ & $\begin{array}{l}\text { c.280T }>\text { A } \\
\text { (p.Trp94Arg) }\end{array}$ & NA & - & - & - & - & $\begin{array}{l}\text { Cerebral } \\
\text { atrophy } \\
\text { Corpus } \\
\text { callosu } \\
\text { m } \\
\text { dysgene } \\
\text { sis } \\
\text { Hypom } \\
\text { yelinati } \\
\text { on } \\
\text { Basal } \\
\text { ganglia } \\
\text { and } \\
\text { thalamu } \\
\text { s } \\
\text { atrophy }\end{array}$ & $\begin{array}{l}\text { Urinary } \\
\text { and } \\
\text { plasma } \\
\text { lactic } \\
\text { acidosis }\end{array}$ & $\begin{array}{l}\text { Dysmorphis } \\
\text { ms } \\
\text { Hepatomega } \\
\text { ly Renal } \\
\text { hypoplasia }\end{array}$ & [75] \\
\hline $\begin{array}{l}\text { TM } \\
\text { EM } \\
70\end{array}$ & $\begin{array}{l}\text { c.317-2A>G (p.?); } \\
\text { c.628A>C } \\
\text { (p.Thr210Pro) }\end{array}$ & $\begin{array}{l}\text { Enceph } \\
\text { alopath } \\
\text { y } \\
\text { Seizures }\end{array}$ & - & - & $\begin{array}{l}\text { Dilated } \\
\text { cardio } \\
\text { myopat } \\
\text { hy }\end{array}$ & $\begin{array}{l}\text { Catar } \\
\text { act } \\
\text { Ptosis }\end{array}$ & $\begin{array}{l}\text { Cortical } \\
\text { atrophy }\end{array}$ & $\begin{array}{l}\text { 3-MGA }{ }^{1} \\
\text { Lactic } \\
\text { acidosis, } \\
\text { Hyperala } \\
\text { ninemia }\end{array}$ & $\begin{array}{l}\text { Dysmorphis } \\
\text { ms } \\
\text { Microcephal } \\
\text { y }\end{array}$ & $\begin{array}{l}{[76]} \\
{[92]} \\
{[80]} \\
{[77]} \\
{[78]}\end{array}$ \\
\hline
\end{tabular}




\begin{tabular}{|c|c|c|c|c|c|}
\hline $\begin{array}{l}\text { c.118_119insGT( } \\
\text { p.Ser40CysfsTer } \\
\text { 11) } \\
\text { c.317-2A>G (p.?) } \\
\text { c.317-2A>G (p.?) } \\
\text { Exon2 deletion }\end{array}$ & $\begin{array}{l}\text { Develop } \\
\text { mental } \\
\text { delay } \\
\text { Motor } \\
\text { delay } \\
\text { Ataxia } \\
\text { Hypoto } \\
\text { nia }\end{array}$ & $\begin{array}{l}\text { Arrhyth } \\
\text { mia } \\
\text { Non- } \\
\text { compac } \\
\mathrm{t} \\
\text { cardio } \\
\text { myopat } \\
\text { hy } \\
\text { Hypertr } \\
\text { ophic } \\
\text { cardio } \\
\text { myopat } \\
\text { hy }\end{array}$ & $\begin{array}{l}\text { hyperam } \\
\text { monaemi } \\
\text { a } \\
\text { Increase } \\
\text { of } \\
\text { ornithine }\end{array}$ & $\begin{array}{l}\text { Hepatomega } \\
\text { ly } \\
\text { Umbilical } \\
\text { hernia }\end{array}$ & $\begin{array}{l}{[81]} \\
{[93]} \\
{[79]}\end{array}$ \\
\hline
\end{tabular}

1 3-MGA: 3-metylglutaconic aciduria

There are increasing evidence of a common mitochondrial energetic dysfunction also in neurodevelopmental disorders. Several genetic disorders whose defects was not primarily localized to mitochondria have been found linked to mitochondrial dysfunction [94]. Fragile X syndrome, a neurodevelopmental disorder characterized by moderate to severe mental retardation, macroorchidism, and distinct facial features, is caused in the majority of cases by an unstable expansion of a CGG repeat in the FMR1 gene and abnormal methylation, which results in suppression of FMR1 transcription and decreased protein levels in the brain [95]. Indeed, in vivo and in vitro models for Fragile $X$ syndrome have demonstrated that FMRP protein regulates closure of the ATP-synthase $c$ subunit leak. Neural and astrocytes cells from Fmr1-/y mice had inefficient respiration and an abnormal "proton leak", which lead to ineffective oxidative phosphorylation [96,97]. Reduced ATP level and mitochondrial respiratory chain defect of complexes III and ATP synthase have been also found in brain tissue of cdkl5 null mice, a disease model for Rett syndrome $[98,99]$.

\section{Neurodegeneration}

The uncoupling of the ATP synthase and hydrolysis processes, dissipation of mitochondrial inner membrane potential, elevated levels of ROS, low matrix content of ATP in combination with other cellular malfunction trigger the opening of the MPTP in the mitochondrial inner membrane, one of the mechanisms responsible of cell death [100].

The opening of the MPTP is activated by a high concentration of $\mathrm{Ca}^{2+}$ in the mitochondrial matrix, inorganic phosphate, CypD and ROS and is linked with the mitochondrial permeability transition $(\mathrm{mPT})$, a phenomenon characterized by the sudden change in the mitochondrial inner membrane permeability to solutes with a size of $<1.5 \mathrm{kDa}[7,9]$. When $\mathrm{mPT}$ occurs, the mechanism of the oxidative phosphorylation is uncoupled by the loss of the membrane potential and the mitochondria undergo swelling and rupture of the outer mitochondrial membrane for osmotic dysregulation with consequent cell death. Other than $\mathrm{Ca}^{2+}$ accumulation inside mitochondria, $\mathrm{mPT}$ requires a protein forming the core channel part of mPTP. Several proteins such as VIDAC, ANT and CypD have been considered a potential forming channel but robust results are for ATP synthase dimers or its $c$-ring, the major component of the membrane Fo complex of the enzyme, as the core channel of mPTP $[50,101,102]$. Indeed, high $\mathrm{Ca}^{2+}$ concentration inhibits the organization of $c$ subunit in fibrils and induces the formation of cross- $\beta$ oligomers, able to form small channels in model lipid bilayers [50,101,101,103,104].

mPT phenomenon together with post-translational modifications and epigenetic modulation of ATP synthase subunits are the mechanism responsible for mitochondrial bioenergetics and dynamics dysfunctions found in brain samples and in vitro and in vitro models of neurogenerative disorders. 
Amilodogenic proteins such $\mathrm{A} \beta$-amiloid and $\alpha$-synuclein can trigger $\mathrm{mPT}$ by direct or indirect activation of ATP synthase contributing to the mechanism of ageing-related disorders.

Parkinson's disease (PD): degeneration of adrenergic neurons in substantia nigra pars compacta and striatum regions cause Parkinson's disease, clinically characterized by motor deficits such as bradykinesia, resting tremor, rigidity, and postural instability [105]. Affected neurons show intracellular deposition of Lewy bodies mostly formed by $\alpha$-synuclein. Studies in rodents and biochemical and histological analysis of patient brain tissues demonstrated mitochondrial OXPHOS deficiencies as well as mitophagy and mtDNA alterations, suggesting the role of mitochondrial dysfunction in the disease pathogenesis. iPSC-derived mutant PARK2 neurons exhibited increased oxidative stress and aberrant activation of the NRF2 pathway with impaired mitochondrial function and $\alpha$-synuclein accumulation [106]. Similarly, iPSC-derived mutant PARK2 dopaminergic neurons, carrying a GFP expression cassette at the TH locus, showed small and less functional neurons with a decline in mitochondrial membrane potential, suggesting a mitochondria-dependent mechanism involved in dopaminergic neuron susceptibility to PD [107]. A potential link between $\alpha$-synuclein and impairments in mitochondrial dynamics and bioenergetics is suggested by the direct interaction with the OXPHOS components as demonstrated in proteomic studies [108,109]. $\alpha$-synuclein aggregates can localise to the mitochondrial membrane and come into close proximity with a number of key mitochondrial proteins such as Complex I and ATP synthase [110,111]. Studies in isolated mitochondria, rodent neurons and human iPSC-derived neurons demonstrated that under physiological conditions monomeric $\alpha$-synuclein interacts with ATP synthase $\alpha$ subunit and enhances ATP synthase activity and mitochondrial function while oligomers interact with the ATP synthase $\beta$ subunit, induce its selective oxidation and mitochondrial lipid peroxidation, affect the catalytic activities of ATP synthase and potentially induce its mPTP-forming activity [112]. In inherited PD due to PARK7 gene defect, the defective protein DJ-1 exert a negative effect on ATP production, consequently causing mitochondrial dysfunction. Indeed, in PARK7 mouse model have been demonstrated that the interaction with the wild-type form of DJ-1 decreased the mitochondrial uncoupling and enhanced ATP production, while defective DJ-1 increased mitochondrial uncoupling and depolarized neuronal mitochondria. The abnormalities of the ATP synthase in DJ-1-/- animals consisted in reduced ATP levels and enzymatic function linked to impairment of neurite extension in isolated dopaminergic neurons. These results suggest that normal ATP synthase function is critical for dopaminergic neuron growth [113].

Alzheimer's disease (AD): AD is one of the most common neurodegenerative disorders, clinically presenting with impairment of memory and executive functions with potential and variable involvement of other domains such as language, visual, or executive functions, are also possible [114]. Pathogenesis is characterized by extracellular $\beta$-amyloid plaques and intracellular hyperphosphorylated tau tangles [115] that causes synaptic dysfunction and neural cell death [100]. Multiple mitochondrial mechanisms may contribute to sporadic AD development, including reduced glucose and oxygen metabolism, altered mitochondrial morphology (e.g. accumulation of osmophilic material, lipofuscin vacuoles, cristae disruption), defective complex IV function, and reduction in mtDNA content [114].

A $\beta$ amyloid can enter into mitochondrial matrix through the Translocase of the Outer Mitochondrial Membrane 40 (TOM40) import channel and the Translocase of the Inner Mitochondrial Membrane 23 (TIM23) import channel which directly interacts with the ATP synthase or indirectly influence its function and stability by interacting with CypD. Consequently, the amilodoigenic protein triggers the $\mathrm{MPT}$ contributing to neurodegeneration $[116,117]$.

ATP synthase catalytic activity is reduced in AD models by post-translational modification such as glycosylation or nitrosylation. Either excess of nitrated $\alpha$ subunit o reduced glycosylation of the O-linked $\beta$-N-acetylglucosamine (O-GlcNAcylated) on the Thr432 residue of $\alpha$ subunit have been associated with reduced ATP synthase activity respectively in the hippocampus of AD patients, $\mathrm{Tg}$ $\mathrm{AD}$ mice and in A $\beta$-treated mammalian cell cultures-resulting in reduced ATP levels $[118,119]$. Moreover, 4-hydroxy-2-nonenal (4-HNE) was demonstrated to modify the $\alpha$ subunit of ATP synthase and decrease ATP hydrolysis in the hippocampal tissue and in the entorhinal cortex of early-stage 
$\mathrm{AD}$ individuals with mild cognitive impairment suggesting that oxidative stress precedes the presence of $A \beta$ in the affected tissue and a 30\%-decreased ATP synthase [120].

Gene expression and protein level analysis of ATP synthase subunits demonstrated an aberrant pattern characterized by a non-uniform increase or decrease of the nuclear and or mitochondrial encoded subunits in patients' brain samples and in vitro and in vivo models. However, further studies are needed to confirm and clarify the mechanism responsible for those variabilities [56].

\section{Conclusions}

To sum up, the functional and bioarchitecture at the molecular and supramolecular structures of ATP synthase reveal the main role in physio(patho)logical conditions. Recent studies have shed light on the mechanisms linking ATP synthase dysfunction and neurodegeneration thereby identifying potentially druggable targets. This will enable the design of new therapies for ageingrelating disorders that will be exploited in further studies in vitro and in vivo models.

Author Contributions: Conceptualization, C.G. and S.N.; writing-original draft preparation, A.P., C.G. and S.N.; writing-review and editing, C.G. and S.N. All authors have read and agreed to the published version of the manuscript.

Funding: This research was funded by CARISBO Foundation, grants numbers 2021.0058 to C.G and 2021.0173 to S.N.; Italian Minister of University and Research - Rita Levi Montalcini Program - Rientro cervelli RLM2017 to C.G.

Conflicts of Interest: The authors declare no conflict of interest.

\section{References}

1. Saraste, M. Oxidative Phosphorylation at the Fin de Siècle. Science 1999, 283, 1488-1493, doi:10.1126/science.283.5407.1488.

2. von Ballmoos, C.; Cook, G.M.; Dimroth, P. Unique Rotary ATP Synthase and Its Biological Diversity. Annu Rev Biophys 2008, 37, 43-64, doi:10.1146/annurev.biophys.37.032807.130018.

3. Nesci, S.; Ventrella, V.; Trombetti, F.; Pirini, M.; Pagliarani, A. Mussel and Mammalian ATP Synthase Share the Same Bioenergetic Cost of ATP. J. Bioenerg. Biomembr. 2013, 45, 289-300, doi:10.1007/s10863-013-9504-1.

4. Paumard, P.; Vaillier, J.; Coulary, B.; Schaeffer, J.; Soubannier, V.; Mueller, D.M.; Brèthes, D.; di Rago, J.-P.; Velours, J. The ATP Synthase Is Involved in Generating Mitochondrial Cristae Morphology. EMBO J. 2002, 21 , 221-230, doi:10.1093/emboj/21.3.221.

5. Elston, T.; Wang, H.; Oster, G. Energy Transduction in ATP Synthase. Nature 1998, 391, 510-513, doi:10.1038/35185.

6. Izzo, V.; Bravo-San Pedro, J.M.; Sica, V.; Kroemer, G.; Galluzzi, L. Mitochondrial Permeability Transition: New Findings and Persisting Uncertainties. Trends Cell Biol. 2016, 26, 655-667, doi:10.1016/j.tcb.2016.04.006.

7. Hunter, D.R.; Haworth, R.A. The Ca2+-Induced Membrane Transition in Mitochondria. I. The Protective Mechanisms. Arch Biochem Biophys 1979, 195, 453-459, doi:10.1016/0003-9861(79)90371-0.

8. Haworth, R.A.; Hunter, D.R. The Ca2+-Induced Membrane Transition in Mitochondria. II. Nature of the Ca2+ Trigger Site. Arch. Biochem. Biophys. 1979, 195, 460-467.

9. Hunter, D.R.; Haworth, R.A. The Ca2+-Induced Membrane Transition in Mitochondria. III. Transitional Ca2+ Release. Arch. Biochem. Biophys. 1979, 195, 468-477.

10. Nesci, S. The Mitochondrial Permeability Transition Pore in Cell Death: A Promising Drug Binding Bioarchitecture. Medicinal Research Reviews 2020, 40, 811-817, doi:10.1002/med.21635.

11. Pérez, M.J.; Quintanilla, R.A. Development or Disease: Duality of the Mitochondrial Permeability Transition Pore. Dev. Biol. 2017, 426, 1-7, doi:10.1016/j.ydbio.2017.04.018. 
12. Nesci, S.; Trombetti, F.; Pagliarani, A.; Ventrella, V.; Algieri, C.; Tioli, G.; Lenaz, G. Molecular and Supramolecular Structure of the Mitochondrial Oxidative Phosphorylation System: Implications for Pathology. Life 2021, 11, 242, doi:10.3390/life11030242.

13. Joshi, A.U.; Mochly-Rosen, D. Mortal Engines: Mitochondrial Bioenergetics and Dysfunction in Neurodegenerative Diseases. Pharmacol. Res. 2018, 138, 2-15, doi:10.1016/j.phrs.2018.08.010.

14. Rampelt, H.; van der Laan, M. The Yin \& Yang of Mitochondrial Architecture - Interplay of MICOS and F1FoATP Synthase in Cristae Formation. Microb Cell 2017, 4, 236-239, doi:10.15698/mic2017.08.583.

15. Wallace, D.C. Bioenergetic Origins of Complexity and Disease. Cold Spring Harb Symp Quant Biol 2011, 76, 116, doi:10.1101/sqb.2011.76.010462.

16. Wolfgang Junge; Nelson, N. ATP Synthase. Annu. Rev. Biochem. 2015, 84, 631-657, doi:10.1146/annurevbiochem-060614-034124.

17. Boyer, P.D. Catalytic Site Occupancy during ATP Synthase Catalysis. FEBS Lett. 2002, 512, 29-32, doi:10.1016/S0014-5793(02)02293-7.

18. Okuno, D.; Iino, R.; Noji, H. Rotation and Structure of FoF1-ATP Synthase. J. Biochem. 2011, 149, 655-664, doi:10.1093/jb/mvr049.

19. Kühlbrandt, W.; Davies, K.M. Rotary ATPases: A New Twist to an Ancient Machine. Trends Biochem. Sci. 2016, 41, 106-116, doi:10.1016/j.tibs.2015.10.006.

20. Nesci, S.; Trombetti, F.; Ventrella, V.; Pagliarani, A. Opposite Rotation Directions in the Synthesis and Hydrolysis of ATP by the ATP Synthase: Hints from a Subunit Asymmetry. J. Membr. Biol. 2015, 248, 163-169, doi:10.1007/s00232-014-9760-y.

21. Boyer, P.D. The ATP Synthase--a Splendid Molecular Machine. Annu. Rev. Biochem. 1997, 66, 717-749, doi:10.1146/annurev.biochem.66.1.717.

22. Hahn, A.; Parey, K.; Bublitz, M.; Mills, D.J.; Zickermann, V.; Vonck, J.; Kühlbrandt, W.; Meier, T. Structure of a Complete ATP Synthase Dimer Reveals the Molecular Basis of Inner Mitochondrial Membrane Morphology. Mol. Cell 2016, 63, 445-456, doi:10.1016/j.molcel.2016.05.037.

23. Frasch, W.D. The Participation of Metals in the Mechanism of the F(1)-ATPase. Biochim. Biophys. Acta 2000, $1458,310-325$.

24. Weber, J.; Bowman, C.; Wilke-Mounts, S.; Senior, A.E. Alpha-Aspartate 261 Is a Key Residue in Noncatalytic Sites of Escherichia Coli F1-ATPase. J. Biol. Chem. 1995, 270, 21045-21049.

25. Pinke, G.; Zhou, L.; Sazanov, L.A. Cryo-EM Structure of the Entire Mammalian F-Type ATP Synthase. Nat Struct Mol Biol 2020, 27, 1077-1085, doi:10.1038/s41594-020-0503-8.

26. Papageorgiou, S.; Melandri, A.B.; Solaini, G. Relevance of Divalent Cations to ATP-Driven Proton Pumping in Beef Heart Mitochondrial F0F1-ATPase. J. Bioenerg. Biomembr. 1998, 30, 533-541.

27. Nesci, S.; Trombetti, F.; Ventrella, V.; Pirini, M.; Pagliarani, A. Kinetic Properties of the Mitochondrial F1FOATPase Activity Elicited by $\mathrm{Ca}(2+)$ in Replacement of $\mathrm{Mg}(2+)$. Biochimie 2017, 140, 73-81, doi:10.1016/j.biochi.2017.06.013.

28. Tucker, W.C.; Schwarz, A.; Levine, T.; Du, Z.; Gromet-Elhanan, Z.; Richter, M.L.; Haran, G. Observation of Calcium-Dependent Unidirectional Rotational Motion in Recombinant Photosynthetic F1-ATPase Molecules. $J$. Biol. Chem. 2004, 279, 47415-47418, doi:10.1074/jbc.C400269200.

29. Nesci, S.; Trombetti, F.; Ventrella, V.; Pagliarani, A. From the Ca2+-Activated F1FO-ATPase to the Mitochondrial Permeability Transition Pore: An Overview. Biochimie 2018, 152, 85-93, doi:10.1016/j.biochi.2018.06.022.

30. Colina-Tenorio, L.; Dautant, A.; Miranda-Astudillo, H.; Giraud, M.-F.; González-Halphen, D. The Peripheral Stalk of Rotary ATPases. Front Physiol 2018, 9, 1243, doi:10.3389/fphys.2018.01243. 
31. Murphy, B.J.; Klusch, N.; Langer, J.; Mills, D.J.; Yildiz, Ö.; Kühlbrandt, W. Rotary Substates of Mitochondrial ATP Synthase Reveal the Basis of Flexible F1-Fo Coupling. Science 2019, 364, doi:10.1126/science.aaw9128.

32. Gu, J.; Zhang, L.; Zong, S.; Guo, R.; Liu, T.; Yi, J.; Wang, P.; Zhuo, W.; Yang, M. Cryo-EM Structure of the Mammalian ATP Synthase Tetramer Bound with Inhibitory Protein IF1. Science 2019, 364, 1068-1075, doi:10.1126/science.aaw4852.

33. Arnold, I.; Pfeiffer, K.; Neupert, W.; Stuart, R.A.; Schägger, H. Yeast Mitochondrial F1F0-ATP Synthase Exists as a Dimer: Identification of Three Dimer-Specific Subunits. EMBO J. 1998, 17, 7170-7178, doi:10.1093/emboj/17.24.7170.

34. Peter, B.J.; Kent, H.M.; Mills, I.G.; Vallis, Y.; Butler, P.J.G.; Evans, P.R.; McMahon, H.T. BAR Domains as Sensors of Membrane Curvature: The Amphiphysin BAR Structure. Science 2004, 303, 495-499, doi:10.1126/science.1092586.

35. Nesci, S.; Pagliarani, A. Ca2+ as Cofactor of the Mitochondrial H+-Translocating F1FO-ATP(Hydrol)Ase. Proteins: Structure, Function, and Bioinformatics 2021, 89, 477-482, doi:https://doi.org/10.1002/prot.26040.

36. Nesci, S.; Pagliarani, A. Incoming News on the F-Type ATPase Structure and Functions in Mammalian Mitochondria. BBA Advances 2021, 1, 100001, doi:10.1016/j.bbadva.2020.100001.

37. Algieri, C.; Trombetti, F.; Pagliarani, A.; Ventrella, V.; Bernardini, C.; Fabbri, M.; Forni, M.; Nesci, S. Mitochondrial Ca2+ -Activated F1 FO -ATPase Hydrolyzes ATP and Promotes the Permeability Transition Pore. Ann. N. Y. Acad. Sci. 2019, 1457, 142-157, doi:10.1111/nyas.14218.

38. Algieri, C.; Trombetti, F.; Pagliarani, A.; Ventrella, V.; Nesci, S. Phenylglyoxal Inhibition of the Mitochondrial F1FO-ATPase Activated by $\mathrm{Mg} 2+$ or by $\mathrm{Ca} 2+$ Provides Clues on the Mitochondrial Permeability Transition Pore. Arch. Biochem. Biophys. 2020, 681, 108258, doi:10.1016/j.abb.2020.108258.

39. Algieri, C.; Nesci, S.; Trombetti, F.; Fabbri, M.; Ventrella, V.; Pagliarani, A. Mitochondrial F1FO-ATPase and Permeability Transition Pore Response to Sulfide in the Midgut Gland of Mytilus Galloprovincialis. Biochimie 2021, 180, 222-228, doi:10.1016/j.biochi.2020.11.012.

40. Algieri, V.; Algieri, C.; Maiuolo, L.; De Nino, A.; Pagliarani, A.; Tallarida, M.A.; Trombetti, F.; Nesci, S. 1,5Disubstituted-1,2,3-Triazoles as Inhibitors of the Mitochondrial Ca2+-Activated F1 FO -ATP(Hydrol)Ase and the Permeability Transition Pore. Ann N Y Acad Sci 2021, 1485, 43-55, doi:10.1111/nyas.14474.

41. Algieri, C.; Trombetti, F.; Pagliarani, A.; Fabbri, M.; Nesci, S. The Inhibition of Gadolinium Ion (Gd3+) on the Mitochondrial F1FO-ATPase Is Linked to the Modulation of the Mitochondrial Permeability Transition Pore. International Journal of Biological Macromolecules 2021, 184, 250-258, doi:10.1016/j.ijbiomac.2021.06.065.

42. Nesci, S.; Algieri, C.; Trombetti, F.; Ventrella, V.; Fabbri, M.; Pagliarani, A. Sulfide Affects the Mitochondrial Respiration, the Ca2+-Activated F1FO-ATPase Activity and the Permeability Transition Pore but Does Not Change the Mg2+-Activated F1FO-ATPase Activity in Swine Heart Mitochondria. Pharmacol Res 2021, 166, 105495, doi:10.1016/j.phrs.2021.105495.

43. Algieri, C.; Trombetti, F.; Pagliarani, A.; Ventrella, V.; Nesci, S. The Mitochondrial F1FO-ATPase Exploits the Dithiol Redox State to Modulate the Permeability Transition Pore. Arch Biochem Biophys 2021, 712, 109027 , doi:10.1016/j.abb.2021.109027.

44. Algieri, C.; Algieri, V.; La Mantia, D.; Bernardini, C.; Maiuolo, L.; Trombetti, F.; Tallarida, M.A.; De Nino, A.; Forni, M.; Pagliarani, A.; et al. New Generation Molecules as Modulators of the Mitochondrial Permeability Transition and Potential Therapeutic Agents. FEBS OPEN BIO 2021, 11, 317.

45. Nesci, S.; Rubattu, S. The ATP Synthase Glycine Zipper of the c Subunits: From the Structural to the Functional Role in Mitochondrial Biology of Cardiovascular Diseases. Biochim Biophys Acta Mol Cell Res 2021, 1868, 119075, doi:10.1016/j.bbamcr.2021.119075. 
46. Nesci, S.; Ventrella, V.; Trombetti, F.; Pirini, M.; Pagliarani, A. Preferential Nitrite Inhibition of the Mitochondrial F1FO-ATPase Activities When Activated by $\mathrm{Ca}(2+)$ in Replacement of the Natural Cofactor $\mathrm{Mg}(2+)$. Biochim. Biophys. Acta 2016, 1860, 345-353, doi:10.1016/j.bbagen.2015.11.004.

47. Antoniel, M.; Jones, K.; Antonucci, S.; Spolaore, B.; Fogolari, F.; Petronilli, V.; Giorgio, V.; Carraro, M.; Di Lisa, F.; Forte, M.; et al. The Unique Histidine in OSCP Subunit of F-ATP Synthase Mediates Inhibition of the Permeability Transition Pore by Acidic PH. EMBO Rep. 2018, 19, 257-268, doi:10.15252/embr.201744705.

48. Guo, L.; Carraro, M.; Carrer, A.; Minervini, G.; Urbani, A.; Masgras, I.; Tosatto, S.C.E.; Szabò, I.; Bernardi, P.; Lippe, G. Arg- 8 of Yeast Subunit e Contributes to the Stability of F-ATP Synthase Dimers and to the Generation of the Full-Conductance Mitochondrial Megachannel. J. Biol. Chem. 2019, 294, 10987-10997, doi:10.1074/jbc.RA119.008775.

49. Guo, L.; Carraro, M.; Sartori, G.; Minervini, G.; Eriksson, O.; Petronilli, V.; Bernardi, P. Arginine 107 of Yeast ATP Synthase Subunit g Mediates Sensitivity of the Mitochondrial Permeability Transition to Phenylglyoxal. $J$. Biol. Chem. 2018, 293, 14632-14645, doi:10.1074/jbc.RA118.004495.

50. Alavian, K.N.; Beutner, G.; Lazrove, E.; Sacchetti, S.; Park, H.-A.; Licznerski, P.; Li, H.; Nabili, P.; Hockensmith, K.; Graham, M.; et al. An Uncoupling Channel within the C-Subunit Ring of the F1FO ATP Synthase Is the Mitochondrial Permeability Transition Pore. Proc. Natl. Acad. Sci. U.S.A. 2014, 111, 10580-10585, doi:10.1073/pnas.1401591111.

51. Bonora, M.; Bononi, A.; De Marchi, E.; Giorgi, C.; Lebiedzinska, M.; Marchi, S.; Patergnani, S.; Rimessi, A.; Suski, J.M.; Wojtala, A.; et al. Role of the c Subunit of the FO ATP Synthase in Mitochondrial Permeability Transition. Cell Cycle 2013, 12, 674-683, doi:10.4161/cc.23599.

52. Giorgio, V.; von Stockum, S.; Antoniel, M.; Fabbro, A.; Fogolari, F.; Forte, M.; Glick, G.D.; Petronilli, V.; Zoratti, M.; Szabó, I.; et al. Dimers of Mitochondrial ATP Synthase Form the Permeability Transition Pore. Proc. Natl. Acad. Sci. U.S.A. 2013, 110, 5887-5892, doi:10.1073/pnas.1217823110.

53. Nesci, S. A Lethal Channel between the ATP Synthase Monomers. Trends Biochem. Sci. 2018, 43, 311-313, doi:10.1016/j.tibs.2018.02.013.

54. Mnatsakanyan, N.; Jonas, E.A. ATP Synthase C-Subunit Ring as the Channel of Mitochondrial Permeability Transition: Regulator of Metabolism in Development and Degeneration. J. Mol. Cell. Cardiol. 2020, 144, 109-118, doi:10.1016/j.yjmcc.2020.05.013.

55. Traxler, L.; Lagerwall, J.; Eichhorner, S.; Stefanoni, D.; D’Alessandro, A.; Mertens, J. Metabolism Navigates Neural Cell Fate in Development, Aging and Neurodegeneration. Dis Model Mech 2021, 14, dmm048993, doi:10.1242/dmm.048993.

56. Galber, C.; Carissimi, S.; Baracca, A.; Giorgio, V. The ATP Synthase Deficiency in Human Diseases. Life (Basel) 2021, 11, 325, doi:10.3390/life11040325.

57. Holt, I.J.; Harding, A.E.; Petty, R.K.; Morgan-Hughes, J.A. A New Mitochondrial Disease Associated with Mitochondrial DNA Heteroplasmy. Am J Hum Genet 1990, 46, 428-433.

58. de Vries, D.D.; van Engelen, B.G.; Gabreëls, F.J.; Ruitenbeek, W.; van Oost, B.A. A Second Missense Mutation in the Mitochondrial ATPase 6 Gene in Leigh's Syndrome. Ann Neurol 1993, 34, 410-412, doi:10.1002/ana.410340319.

59. Sgarbi, G.; Baracca, A.; Lenaz, G.; Valentino, L.M.; Carelli, V.; Solaini, G. Inefficient Coupling between Proton Transport and ATP Synthesis May Be the Pathogenic Mechanism for NARP and Leigh Syndrome Resulting from the T8993G Mutation in MtDNA. Biochem J 2006, 395, 493-500, doi:10.1042/BJ20051748.

60. Lott, M.T.; Leipzig, J.N.; Derbeneva, O.; Xie, H.M.; Chalkia, D.; Sarmady, M.; Procaccio, V.; Wallace, D.C. MtDNA Variation and Analysis Using Mitomap and Mitomaster. Curr Protoc Bioinformatics 2013, 44, 1.23.1-26, doi:10.1002/0471250953.bi0123s44. 
61. Carrozzo, R.; Tessa, A.; Vázquez-Memije, M.E.; Piemonte, F.; Patrono, C.; Malandrini, A.; Dionisi-Vici, C.; Vilarinho, L.; Villanova, M.; Schägger, H.; et al. The T9176G MtDNA Mutation Severely Affects ATP Production and Results in Leigh Syndrome. Neurology 2001, 56, 687-690, doi:10.1212/wnl.56.5.687.

62. Vazquez-Memije, M.E.; Rizza, T.; Meschini, M.C.; Nesti, C.; Santorelli, F.M.; Carrozzo, R. Cellular and Functional Analysis of Four Mutations Located in the Mitochondrial ATPase6 Gene. J Cell Biochem 2009, 106, 878-886, doi:10.1002/jcb.22055.

63. Tońska, K.; Kodroń, A.; Bartnik, E. Genotype-Phenotype Correlations in Leber Hereditary Optic Neuropathy. Biochim Biophys Acta 2010, 1797, 1119-1123, doi:10.1016/j.bbabio.2010.02.032.

64. Pitceathly, R.D.S.; Murphy, S.M.; Cottenie, E.; Chalasani, A.; Sweeney, M.G.; Woodward, C.; Mudanohwo, E.E.; Hargreaves, I.; Heales, S.; Land, J.; et al. Genetic Dysfunction of MT-ATP6 Causes Axonal Charcot-Marie-Tooth Disease. Neurology 2012, 79, 1145-1154, doi:10.1212/WNL.0b013e3182698d8d.

65. Hejzlarová, K.; Mráček, T.; Vrbacký, M.; Kaplanová, V.; Karbanová, V.; Nůsková, H.; Pecina, P.; Houštěk, J. Nuclear Genetic Defects of Mitochondrial ATP Synthase. Physiol Res 2014, 63, S57-71, doi:10.33549/physiolres.932643.

66. Mordel, P.; Schaeffer, S.; Dupas, Q.; Laville, M.-A.; Gérard, M.; Chapon, F.; Allouche, S. A 2 Bp Deletion in the Mitochondrial ATP 6 Gene Responsible for the NARP (Neuropathy, Ataxia, and Retinitis Pigmentosa) Syndrome. Biochem Biophys Res Commun 2017, 494, 133-137, doi:10.1016/j.bbrc.2017.10.066.

67. Mkaouar-Rebai, E.; Kammoun, F.; Chamkha, I.; Kammoun, N.; Hsairi, I.; Triki, C.; Fakhfakh, F. A de Novo Mutation in the Adenosine Triphosphatase (ATPase) 8 Gene in a Patient with Mitochondrial Disorder. $J$ Child Neurol 2010, 25, 770-775, doi:10.1177/0883073809344351.

68. Felhi, R.; Mkaouar-Rebai, E.; Sfaihi-Ben Mansour, L.; Alila-Fersi, O.; Tabebi, M.; Ben Rhouma, B.; Ammar, M.; Keskes, L.; Hachicha, M.; Fakhfakh, F. Mutational Analysis in Patients with Neuromuscular Disorders: Detection of Mitochondrial Deletion and Double Mutations in the MT-ATP6 Gene. Biochem Biophys Res Commun 2016, 473, 61-66, doi:10.1016/j.bbrc.2016.03.050.

69. Jonckheere, A.I.; Renkema, G.H.; Bras, M.; van den Heuvel, L.P.; Hoischen, A.; Gilissen, C.; Nabuurs, S.B.; Huynen, M.A.; de Vries, M.C.; Smeitink, J.A.M.; et al. A Complex V ATP5A1 Defect Causes Fatal Neonatal Mitochondrial Encephalopathy. Brain 2013, 136, 1544-1554, doi:10.1093/brain/awt086.

70. Lieber, D.S.; Calvo, S.E.; Shanahan, K.; Slate, N.G.; Liu, S.; Hershman, S.G.; Gold, N.B.; Chapman, B.A.; Thorburn, D.R.; Berry, G.T.; et al. Targeted Exome Sequencing of Suspected Mitochondrial Disorders. Neurology 2013, 80, 1762-1770, doi:10.1212/WNL.0b013e3182918c40.

71. Oláhová, M.; Yoon, W.H.; Thompson, K.; Jangam, S.; Fernandez, L.; Davidson, J.M.; Kyle, J.E.; Grove, M.E.; Fisk, D.G.; Kohler, J.N.; et al. Biallelic Mutations in ATP5F1D, Which Encodes a Subunit of ATP Synthase, Cause a Metabolic Disorder. Am J Hum Genet 2018, 102, 494-504, doi:10.1016/j.ajhg.2018.01.020.

72. Tort, F.; García-Silva, M.T.; Ferrer-Cortès, X.; Navarro-Sastre, A.; Garcia-Villoria, J.; Coll, M.J.; Vidal, E.; Jiménez-Almazán, J.; Dopazo, J.; Briones, P.; et al. Exome Sequencing Identifies a New Mutation in SERAC1 in a Patient with 3-Methylglutaconic Aciduria. Mol Genet Metab 2013, 110, 73-77, doi:10.1016/j.ymgme.2013.04.021.

73. Mayr, J.A.; Havlícková, V.; Zimmermann, F.; Magler, I.; Kaplanová, V.; Jesina, P.; Pecinová, A.; Nusková, H.; Koch, J.; Sperl, W.; et al. Mitochondrial ATP Synthase Deficiency Due to a Mutation in the ATP5E Gene for the F1 Epsilon Subunit. Hum Mol Genet 2010, 19, 3430-3439, doi:10.1093/hmg/ddq254.

74. Barca, E.; Ganetzky, R.D.; Potluri, P.; Juanola-Falgarona, M.; Gai, X.; Li, D.; Jalas, C.; Hirsch, Y.; Emmanuele, V.; Tadesse, S.; et al. USMG5 Ashkenazi Jewish Founder Mutation Impairs Mitochondrial Complex V Dimerization and ATP Synthesis. Hum Mol Genet 2018, 27, 3305-3312, doi:10.1093/hmg/ddy231. 
75. De Meirleir, L.; Seneca, S.; Lissens, W.; De Clercq, I.; Eyskens, F.; Gerlo, E.; Smet, J.; Van Coster, R. Respiratory Chain Complex V Deficiency Due to a Mutation in the Assembly Gene ATP12. J Med Genet 2004, 41, 120-124, doi:10.1136/jmg.2003.012047.

76. Stojanović, V.; Doronjski, A. Mild Form of 3-Methylglutaconic Aciduria Type IV and Mutation in the TMEM70 Genes. J Pediatr Endocrinol Metab 2013, 26, 151-154, doi:10.1515/jpem-2012-0291.

77. Honzík, T.; Tesarová, M.; Mayr, J.A.; Hansíková, H.; Jesina, P.; Bodamer, O.; Koch, J.; Magner, M.; Freisinger, P.; Huemer, M.; et al. Mitochondrial Encephalocardio-Myopathy with Early Neonatal Onset Due to TMEM70 Mutation. Arch Dis Child 2010, 95, 296-301, doi:10.1136/adc.2009.168096.

78. Torraco, A.; Verrigni, D.; Rizza, T.; Meschini, M.C.; Vazquez-Memije, M.E.; Martinelli, D.; Bianchi, M.; Piemonte, F.; Dionisi-Vici, C.; Santorelli, F.M.; et al. TMEM70: A Mutational Hot Spot in Nuclear ATP Synthase Deficiency with a Pivotal Role in Complex V Biogenesis. Neurogenetics 2012, 13, 375-386, doi:10.1007/s10048012-0343-8.

79. Jonckheere, A.I.; Huigsloot, M.; Lammens, M.; Jansen, J.; van den Heuvel, L.P.; Spiekerkoetter, U.; von KleistRetzow, J.-C.; Forkink, M.; Koopman, W.J.H.; Szklarczyk, R.; et al. Restoration of Complex V Deficiency Caused by a Novel Deletion in the Human TMEM70 Gene Normalizes Mitochondrial Morphology. Mitochondrion 2011, 11, 954-963, doi:10.1016/j.mito.2011.08.012.

80. Wortmann, S.B.; Rodenburg, R.J.T.; Jonckheere, A.; de Vries, M.C.; Huizing, M.; Heldt, K.; van den Heuvel, L.P.; Wendel, U.; Kluijtmans, L.A.; Engelke, U.F.; et al. Biochemical and Genetic Analysis of 3-Methylglutaconic Aciduria Type IV: A Diagnostic Strategy. Brain 2009, 132, 136-146, doi:10.1093/brain/awn296.

81. Braczynski, A.K.; Vlaho, S.; Müller, K.; Wittig, I.; Blank, A.-E.; Tews, D.S.; Drott, U.; Kleinle, S.; Abicht, A.; Horvath, R.; et al. ATP Synthase Deficiency Due to TMEM70 Mutation Leads to Ultrastructural Mitochondrial Degeneration and Is Amenable to Treatment. Biomed Res Int 2015, 2015, 462592, doi:10.1155/2015/462592.

82. Hung, P.-C.; Wang, H.-S. A Previously Undescribed Leukodystrophy in Leigh Syndrome Associated with T9176C Mutation of the Mitochondrial ATPase 6 Gene. Dev Med Child Neurol 2007, 49, 65-67, doi:10.1017/s0012162207000163.x.

83. Verny, C.; Guegen, N.; Desquiret, V.; Chevrollier, A.; Prundean, A.; Dubas, F.; Cassereau, J.; Ferre, M.; AmatiBonneau, P.; Bonneau, D.; et al. Hereditary Spastic Paraplegia-like Disorder Due to a Mitochondrial ATP6 Gene Point Mutation. Mitochondrion 2011, 11, 70-75, doi:10.1016/j.mito.2010.07.006.

84. Synofzik, M.; Schicks, J.; Wilhelm, C.; Bornemann, A.; Schöls, L. Charcot-Marie-Tooth Hereditary Neuropathy Due to a Mitochondrial ATP6 Mutation. Eur J Neurol 2012, 19, e114-116, doi:10.1111/j.1468-1331.2012.03812.x.

85. Yu, X.-L.; Yan, C.-Z.; Ji, K.-Q.; Lin, P.-F.; Xu, X.-B.; Dai, T.-J.; Li, W.; Zhao, Y.-Y. Clinical, Neuroimaging, and Pathological Analyses of 13 Chinese Leigh Syndrome Patients with Mitochondrial DNA Mutations. Chin Med J (Engl) 2018, 131, 2705-2712, doi:10.4103/0366-6999.245265.

86. Hu, C.; Li, X.; Zhao, L.; Shi, Y.; Zhou, S.; Wu, B.; Wang, Y. Clinical and Molecular Characterization of Pediatric Mitochondrial Disorders in South of China. Eur J Med Genet 2020, 63, 103898, doi:10.1016/j.ejmg.2020.103898.

87. Spangenberg, L.; Graña, M.; Mansilla, S.; Martínez, J.; Tapié, A.; Greif, G.; Montano, N.; Vaglio, A.; Gueçaimburú, R.; Robello, C.; et al. Deep Sequencing Discovery of Causal MtDNA Mutations in a Patient with Unspecific Neurological Disease. Mitochondrion 2019, 46, 337-344, doi:10.1016/j.mito.2018.09.004.

88. López-Gallardo, E.; Emperador, S.; Solano, A.; Llobet, L.; Martín-Navarro, A.; López-Pérez, M.J.; Briones, P.; Pineda, M.; Artuch, R.; Barraquer, E.; et al. Expanding the Clinical Phenotypes of MT-ATP6 Mutations. Hum Mol Genet 2014, 23, 6191-6200, doi:10.1093/hmg/ddu339.

89. Mkaouar-Rebai, E.; Felhi, R.; Tabebi, M.; Alila-Fersi, O.; Chamkha, I.; Maalej, M.; Ammar, M.; Kammoun, F.; Keskes, L.; Hachicha, M.; et al. Mitochondrial DNA Triplication and Punctual Mutations in Patients with 
Mitochondrial Neuromuscular Disorders. Biochem Biophys Res Commun 2016, 473, 578-585, doi:10.1016/j.bbrc.2016.03.126.

90. Claeys, K.G.; Abicht, A.; Häusler, M.; Kleinle, S.; Wiesmann, M.; Schulz, J.B.; Horvath, R.; Weis, J. Novel Genetic and Neuropathological Insights in Neurogenic Muscle Weakness, Ataxia, and Retinitis Pigmentosa (NARP). Muscle Nerve 2016, 54, 328-333, doi:10.1002/mus.25125.

91. Lemoine, S.; Panaye, M.; Rabeyrin, M.; Errazuriz-Cerda, E.; Mousson de Camaret, B.; Petiot, P.; Juillard, L.; Guebre-Egziabher, F. Renal Involvement in Neuropathy, Ataxia, Retinitis Pigmentosa (NARP) Syndrome: A Case Report. Am J Kidney Dis 2018, 71, 754-757, doi:10.1053/j.ajkd.2017.09.020.

92. Tort, F.; Del Toro, M.; Lissens, W.; Montoya, J.; Fernàndez-Burriel, M.; Font, A.; Buján, N.; Navarro-Sastre, A.; López-Gallardo, E.; Arranz, J.A.; et al. Screening for Nuclear Genetic Defects in the ATP Synthase-Associated Genes TMEM70, ATP12 and ATP5E in Patients with 3-Methylglutaconic Aciduria. Clin Genet 2011, 80, 297-300, doi:10.1111/j.1399-0004.2011.01650.x.

93. Cameron, J.M.; Levandovskiy, V.; Mackay, N.; Ackerley, C.; Chitayat, D.; Raiman, J.; Halliday, W.H.; Schulze, A.; Robinson, B.H. Complex V TMEM70 Deficiency Results in Mitochondrial Nucleoid Disorganization. Mitochondrion 2011, 11, 191-199, doi:10.1016/j.mito.2010.09.008.

94. Ortiz-González, X.R. Mitochondrial Dysfunction: A Common Denominator in Neurodevelopmental Disorders? Dev Neurosci 2021, 43, 222-229, doi:10.1159/000517870.

95. Devys, D.; Lutz, Y.; Rouyer, N.; Bellocq, J.P.; Mandel, J.L. The FMR-1 Protein Is Cytoplasmic, Most Abundant in Neurons and Appears Normal in Carriers of a Fragile X Premutation. Nat Genet 1993, 4, 335-340, doi:10.1038/ng0893-335.

96. Griffiths, K.K.; Wang, A.; Wang, L.; Tracey, M.; Kleiner, G.; Quinzii, C.M.; Sun, L.; Yang, G.; Perez-Zoghbi, J.F.; Licznerski, P.; et al. Inefficient Thermogenic Mitochondrial Respiration Due to Futile Proton Leak in a Mouse Model of Fragile X Syndrome. FASEB J 2020, 34, 7404-7426, doi:10.1096/fj.202000283RR.

97. Licznerski, P.; Park, H.-A.; Rolyan, H.; Chen, R.; Mnatsakanyan, N.; Miranda, P.; Graham, M.; Wu, J.; CruzReyes, N.; Mehta, N.; et al. ATP Synthase C-Subunit Leak Causes Aberrant Cellular Metabolism in Fragile X Syndrome. Cell 2020, 182, 1170-1185.e9, doi:10.1016/j.cell.2020.07.008.

98. Carli, S.; Chaabane, L.; Butti, C.; De Palma, C.; Aimar, P.; Salio, C.; Vignoli, A.; Giustetto, M.; Landsberger, N.; Frasca, A. In Vivo Magnetic Resonance Spectroscopy in the Brain of Cdk15 Null Mice Reveals a Metabolic Profile Indicative of Mitochondrial Dysfunctions. J Neurochem 2021, 157, 1253-1269, doi:10.1111/jnc.15300.

99. de Martynoff, G.; Pohl, V.; Mercken, L.; van Ommen, G.J.; Vassart, G. Structural Organization of the Bovine Thyroglobulin Gene and of Its 5'-Flanking Region. Eur J Biochem 1987, 164, 591-599, doi:10.1111/j.14321033.1987.tb11168.x.

100. Mnatsakanyan, N.; Jonas, E.A. The New Role of F1Fo ATP Synthase in Mitochondria-Mediated Neurodegeneration and Neuroprotection. Experimental Neurology 2020, 332, doi:10.1016/j.expneurol.2020.113400.

101. Amodeo, G.F.; Solesio, M.E.; Pavlov, E.V. From ATP Synthase Dimers to C-Ring Conformational Changes: Unified Model of the Mitochondrial Permeability Transition Pore. Cell Death Dis 2017, 8, 1, doi:10.1038/s41419017-0042-3

102. Neginskaya, M.A.; Solesio, M.E.; Berezhnaya, E.V.; Amodeo, G.F.; Mnatsakanyan, N.; Jonas, E.A.; Pavlov, E.V. ATP Synthase C-Subunit-Deficient Mitochondria Have a Small Cyclosporine A-Sensitive Channel, but Lack the Permeability Transition Pore. Cell Rep 2019, 26, 11-17.e2, doi:10.1016/j.celrep.2018.12.033.

103. Bonora, M.; Pinton, P. A New Current for the Mitochondrial Permeability Transition. Trends Biochem Sci 2019, 44, 559-561, doi:10.1016/j.tibs.2019.04.009. 
104. Amodeo, G.F.; Lee, B.Y.; Krilyuk, N.; Filice, C.T.; Valyuk, D.; Otzen, D.E.; Noskov, S.; Leonenko, Z.; Pavlov, E.V. C Subunit of the ATP Synthase Is an Amyloidogenic Calcium Dependent Channel-Forming Peptide with Possible Implications in Mitochondrial Permeability Transition. Sci Rep 2021, 11, 8744, doi:10.1038/s41598-021$88157-\mathrm{z}$

105. Shulman, J.M.; De Jager, P.L.; Feany, M.B. Parkinson's Disease: Genetics and Pathogenesis. Annu Rev Pathol 2011, 6, 193-222, doi:10.1146/annurev-pathol-011110-130242.

106. Imaizumi, Y.; Okada, Y.; Akamatsu, W.; Koike, M.; Kuzumaki, N.; Hayakawa, H.; Nihira, T.; Kobayashi, T.; Ohyama, M.; Sato, S.; et al. Mitochondrial Dysfunction Associated with Increased Oxidative Stress and $\alpha$ Synuclein Accumulation in PARK2 IPSC-Derived Neurons and Postmortem Brain Tissue. Mol Brain 2012, 5, 35, doi:10.1186/1756-6606-5-35.

107. Yokota, M.; Kakuta, S.; Shiga, T.; Ishikawa, K.-I.; Okano, H.; Hattori, N.; Akamatsu, W.; Koike, M. Establishment of an in Vitro Model for Analyzing Mitochondrial Ultrastructure in PRKN-Mutated Patient IPSC-Derived Dopaminergic Neurons. Mol Brain 2021, 14, 58, doi:10.1186/s13041-021-00771-0.

108. Pozo Devoto, V.M.; Falzone, T.L. Mitochondrial Dynamics in Parkinson's Disease: A Role for $\alpha$-Synuclein? Dis Model Mech 2017, 10, 1075-1087, doi:10.1242/dmm.026294.

109. Rango, M.; Bresolin, N. Brain Mitochondria, Aging, and Parkinson's Disease. Genes (Basel) 2018, 9, E250, doi:10.3390/genes9050250.

110. Luth, E.S.; Stavrovskaya, I.G.; Bartels, T.; Kristal, B.S.; Selkoe, D.J. Soluble, Prefibrillar $\alpha$-Synuclein Oligomers Promote Complex I-Dependent, Ca2+-Induced Mitochondrial Dysfunction. J Biol Chem 2014, 289, 21490-21507, doi:10.1074/jbc.M113.545749.

111. Ludtmann, M.H.R.; Angelova, P.R.; Ninkina, N.N.; Gandhi, S.; Buchman, V.L.; Abramov, A.Y. Monomeric Alpha-Synuclein Exerts a Physiological Role on Brain ATP Synthase. J Neurosci 2016, 36, 10510-10521, doi:10.1523/JNEUROSCI.1659-16.2016.

112. Ludtmann, M.H.R.; Angelova, P.R.; Horrocks, M.H.; Choi, M.L.; Rodrigues, M.; Baev, A.Y.; Berezhnov, A.V.; Yao, Z.; Little, D.; Banushi, B.; et al. $\alpha$-Synuclein Oligomers Interact with ATP Synthase and Open the Permeability Transition Pore in Parkinson's Disease. Nat Commun 2018, 9, 2293, doi:10.1038/s41467-018-044222.

113. Chen, R.; Park, H.-A.; Mnatsakanyan, N.; Niu, Y.; Licznerski, P.; Wu, J.; Miranda, P.; Graham, M.; Tang, J.; Boon, A.J.W.; et al. Parkinson's Disease Protein DJ-1 Regulates ATP Synthase Protein Components to Increase Neuronal Process Outgrowth. Cell Death Dis 2019, 10, 469, doi:10.1038/s41419-019-1679-x.

114. Monzio Compagnoni, G.; Di Fonzo, A.; Corti, S.; Comi, G.P.; Bresolin, N.; Masliah, E. The Role of Mitochondria in Neurodegenerative Diseases: The Lesson from Alzheimer's Disease and Parkinson's Disease. Mol Neurobiol 2020, 57, 2959-2980, doi:10.1007/s12035-020-01926-1.

115. DeTure, M.A.; Dickson, D.W. The Neuropathological Diagnosis of Alzheimer's Disease. Mol Neurodegener 2019, 14, 32, doi:10.1186/s13024-019-0333-5.

116. Devi, L.; Prabhu, B.M.; Galati, D.F.; Avadhani, N.G.; Anandatheerthavarada, H.K. Accumulation of Amyloid Precursor Protein in the Mitochondrial Import Channels of Human Alzheimer's Disease Brain Is Associated with Mitochondrial Dysfunction. J Neurosci 2006, 26, 9057-9068, doi:10.1523/JNEUROSCI.1469-06.2006.

117. Beck, S.J.; Guo, L.; Phensy, A.; Tian, J.; Wang, L.; Tandon, N.; Gauba, E.; Lu, L.; Pascual, J.M.; Kroener, S.; et al. Deregulation of Mitochondrial F1FO-ATP Synthase via OSCP in Alzheimer's Disease. Nat Commun 2016, 7 , 11483, doi:10.1038/ncomms11483.

118. Cha, M.-Y.; Cho, H.J.; Kim, C.; Jung, Y.O.; Kang, M.J.; Murray, M.E.; Hong, H.S.; Choi, Y.-J.; Choi, H.; Kim, D.K.; et al. Mitochondrial ATP Synthase Activity Is Impaired by Suppressed O-GlcNAcylation in Alzheimer's Disease. Hum Mol Genet 2015, 24, 6492-6504, doi:10.1093/hmg/ddv358. 
119. Sultana, R.; Poon, H.F.; Cai, J.; Pierce, W.M.; Merchant, M.; Klein, J.B.; Markesbery, W.R.; Butterfield, D.A. Identification of Nitrated Proteins in Alzheimer's Disease Brain Using a Redox Proteomics Approach. Neurobiol Dis 2006, 22, 76-87, doi:10.1016/j.nbd.2005.10.004.

120. Reed, T.; Perluigi, M.; Sultana, R.; Pierce, W.M.; Klein, J.B.; Turner, D.M.; Coccia, R.; Markesbery, W.R.; Butterfield, D.A. Redox Proteomic Identification of 4-Hydroxy-2-Nonenal-Modified Brain Proteins in Amnestic Mild Cognitive Impairment: Insight into the Role of Lipid Peroxidation in the Progression and Pathogenesis of Alzheimer's Disease. Neurobiol Dis 2008, 30, 107-120, doi:10.1016/j.nbd.2007.12.007.

(C) 2020 by the authors. Submitted for possible open access publication under the terms and conditions of the Creative Commons Attribution (CC BY) license (http://creativecommons.org/licenses/by/4.0/). 